\title{
糖尿病態モデル及び肥満症モデルに対する防已黄耆湯及び防風通聖散の薬理作用機序
}

\author{
古林伸二郎†
}

\section{Pharmacological Mechanisms of Boiogito and Bofutsushosan in Diabetes and Obesity Models}

\author{
Shinjiro Kobayashi ${ }^{\dagger}$ \\ Faculty of Pharmaceutical Sciences, Hokuriku University; Ho-3 \\ Kanagawa-machi, Kanazawa, Ishikawa 920-1181, Japan.
}

(Received July 9, 2017)

\begin{abstract}
The antihyperglycemic activities of extracts of boiogito (BOT) and bofutsushosan (BTS) were investigated in streptozotocin-induced (STZ)-diabetic mice. BOT extract containing Stephania tetrandra S. MooRE root (stephania), has more potent antihyperglycemic activity than BOT extract containing sinomenium stem (sinomenium). Extracts of stephania and astragalus root (astragalus) exert combined effects in the antihyperglycemic and insulinotropic activities of BOT extract. Fangchinoline, but not tetrandrine, in stephania plays a role in its activity. Formononetin in astragalus potentiates the actions of fangchinoline. Tetrandrine has antiangiogenic effects on choroidal vessels in STZ-diabetic rats, which are associated with the inhibition of tumor necrosis factor $(\mathrm{TNF})-\alpha$-induced nuclear factor $(\mathrm{NF})-\kappa \mathrm{B}$ activation. BTS extract has shown antihyperglycemic and insulinotropic activities whereas gardenia fruit (gardenia) extract in BTS has antihyperglycemic, but not insulinotropic, activity in the diabetic mice. Gardenia extract decreased the HOMA-IR level and increased insulin-stimulated 2-deoxyglucose (2-DG) uptake to skeletal muscle. The effects of gardenia extract on 2-DG uptake were associated with the upregulation of glucose transporter type 4 and Akt phosphorylation. Gardenia extract was also shown to have antihyperglycemic and insulinotropic actions in high-fat diet (HFD) -fed and STZ-diabetic mice. In addition, gardenia extract decreased the production of TNF- $\alpha$ and leptin, and increased the production of adiponectin in the visceral adipose tissues. In the early administration period, BTS extract increased mRNA expression levels of leptin, adiponectin, and UCP1 in brown adipose tissues in HFD-fed obese mice. With a longer duration of administration, BTS extract improved insulin resistance and subsequently reduced serum leptin and triglyceride levels in parallel with visceral adipose tissue volume and size.
\end{abstract}

Key words_ - boiogito; bofutsushosan; combined effect; streptozotocin-induced diabetes; high-fat diet

\section{1.はじめに}

筆者は 1970 年に富山大学薬学部に入学し, 1973 年に卒研生として薬品作用学講座（木村正康教授） に配属された。卒業後大学院修士課程及び日本学術 振興会薬学奨励研究生として同講座で研究を続け, 薬学博士を取得したが, その研究課題は漢方薬に関 連したものではなかった。本格的な漢方薬研究は富 山医科薬科大学助手時代に木村教授のお手伝いから 始まり，慢性炎症モデルに対する漢方方剂の薬理学 的研究の方法論を身に付けることができた. ${ }^{1)} 1995$

北陸大学薬学部（T920-1181 石川県金沢市金川町ホ 3 番地)

現所属: †テイカ製薬株式会社研究所（テ930-0982 富 山市荒川 1 丁目 3 番 27 号)

e-mail: kobayashi-gakuendai@nifty.com

本総説は, 平成 28 年度退職にあたり在職中の業績を中 心に記述されたものである.
年には, 縁あって北陸大学薬学部薬理学講座に助教 授として赴任した。当時, 北陸大学薬学部は東洋医 薬学の教育研究を推進していたので, まず, streptozotocin（STZ）-糖尿病態モデルに対する防已黄者 湯の効果に関する教育研究から始めた.

2. STZ-糖尿病態マウスの血糖値に対する防已 黄耆湯の抑制効果

防已黄耆湯は日本では防已と黄耆, 蒼术, 生姜, 大雵, 甘草からなる方剂であり, 中国では防已の代 わりに粉防已が用いられている。粉防已は古くは日 本薬局方に収載されていたが，現在は削除されてい る。まず，日本の防已黄耆湯エキスと中国の防已黄 者湯エキスを用いて，STZ-糖尿病態マウスの血糖 值に対する効果を比較した. ${ }^{2}$ 粉防已を含む防已黄 耆湯エキスは，絶食下で 6 時間腹腔内投与により， 用量依存的に血糖值を低下させた。防已を含む防已 
STZ-Diabetic Mice (Fasted)

6 hours after i.p. administration
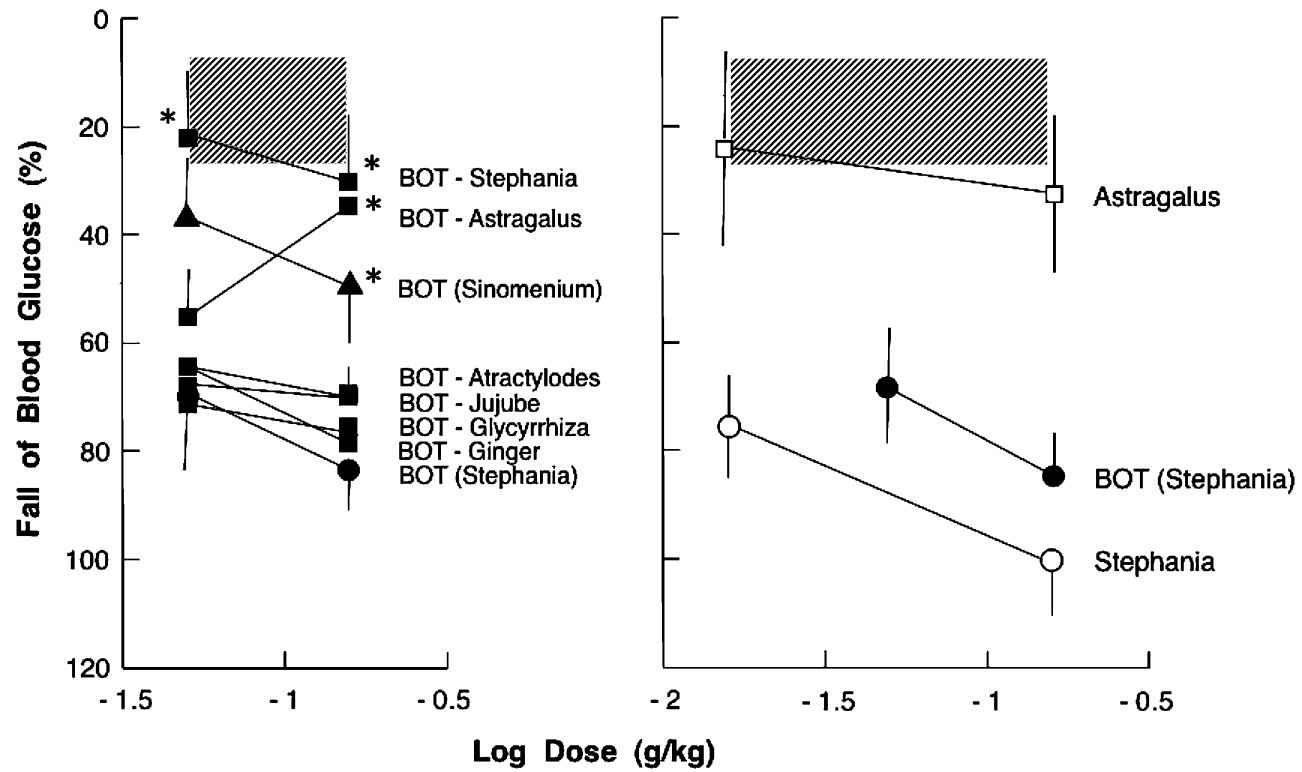

Fig. 1. Antihyperglycemic Effects of BOT (Stephania; O) Extract, BOT (Sinomenium; $\mathbf{\Delta}$ ) Extract, and Extracts of BOT (Stephania) without a Composed Individual Crude Drug (BOT-Stephania, BOT-Astragalus, BOT-Atractylodes, BOT-Jujube, BOT-Glycyrrhiza, BOT-Ginger; $\mathbf{\square}$ ) (left), and Extracts of Astragalus ( $\square$ ), Stephania (O), and BOT (Stephania; O) (right) in STZ-diabetic Mice

Blood glucose (BG) levels were measured before and $6 \mathrm{~h}$ after intraperitoneal administration of drugs. The decrease in BG (\%) was calculated as [BG (before drug treatment) - BG (after drug treatment) $/$ BG (before drug treatment) -85$] \times 100$. Values are expressed as mean \pm S.E.M. of data from 5-8 mice. Shadowed columns represent ranges of S.E.M. in data from 7 or 8 mice in saline alone. ${ }^{*} p<0.05$ versus BOT (Stephania) extract. Reproduced, with permission, from Liu et al., 2000. ${ }^{2}$

黄者湯エキスは，粉防已を含むものと比較して血糖 降下作用や insulin 分泌作用が有意に弱かった (Fig. 1). 2) 以上から，防已黄者湯エキスは，防已を 粉防已に変更することにより，より強力な血糖下降 作用が得られることがわかった。そこで，粉防已を 含む防已黄耆湯エキスの血糖降下作用を詳細に検討 した。まず，構成生薬の複合作用を解明するため に，防已黄耆湯エキスと防已黄耆湯の一味抜き方剂 エキスの効果を比較した。粉防已抜き方剂エキスと 黄耆抜き方剤エキスは，粉防已を含む防已黄耆湯工 キスの作用を完全に消失させた。しかし，蒼术抜き 方剂エキスや生姜抜き方剂エキス，大雵抜き方剂工 キス，甘草抜き方剤エキスは，粉防已を含む防已黄 者湯エキスと同程度の作用を維持していた（Fig. 1)。以上の結果は，粉防已を含む防已黄者湯エキス は，STZ-糖尿病態の血糖下降作用において粉防已 と黄耆間に複合作用を有することを示した。しか し，蒼术や生姜，大霜，甘草はこの複合作用に関与 しなかった。粉防已エキスと黄耆エキスを単独に作 用させると，粉防已エキスは糖尿病態の高血糖を低 下させたが，黄者エキスは高血糖に影響しなかった
（Fig. 1)。そこで，粉防已と黄者を防已黄者湯中と 同じ比率で混合して得たエキスの作用を検討する と, ${ }^{3)}$ 黄者エキスは，単独作用を持たないが，粉防 已エキスの単独作用を増強するという全く新しい事 実を見い出すことができた [Fig. 2(A)]．この血糖 降下作用における粉防已エキスと黄耆エキスの複合 作用は insulin 分泌作用においてもみられたので [Fig. 2(B) ]，黄者エキスは粉防已エキスの insulin 分泌作用を増強して, 糖尿病態の血糖值を低下させ ることを明らかにした。

粉防已の主要成分の 1 つである fangchinoline は 粉防已エキスより強力な血糖下降作用を有したが,

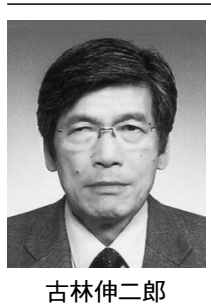

1974 年富山大学大学院薬学研究科修士 課程修了後, 日本学術振興会薬学奨励 研究生となり, 1983 年薬学博士取得. 米国ペンシルバニア大学医学部博士研 究員, 1986 年富山医科薬科大学薬学部 助手, 講師を経て, 1995 年北陸大学薬 学部助教授, 2004 年同教授に至り, 2017 年 3 月に定年退職した。 1995 年和 漢医薬学会奨励賞を契機に漢方薬研究 を継続中 
A. STZ-Diabetic Mice (Fasted) 6 hours after i.p. administration

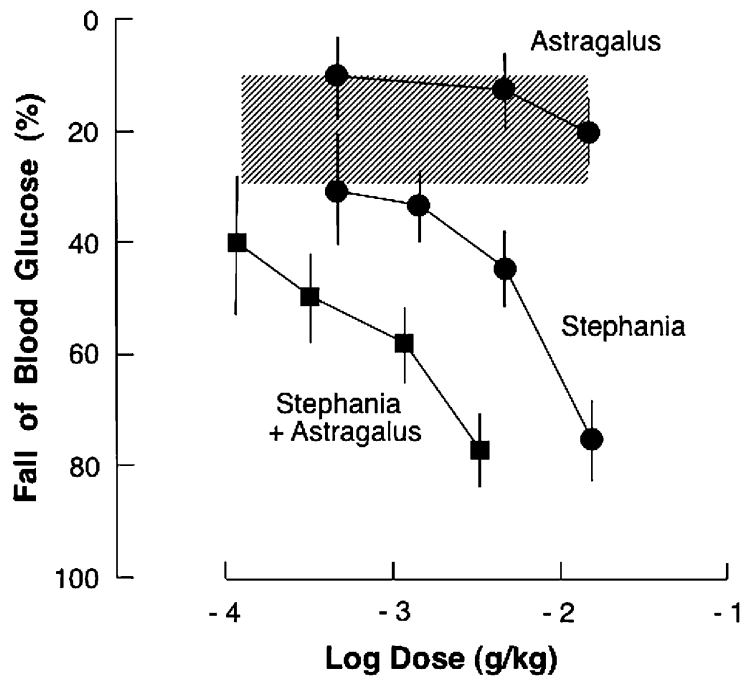

B. STZ-Diabetic Mice (Fasted)

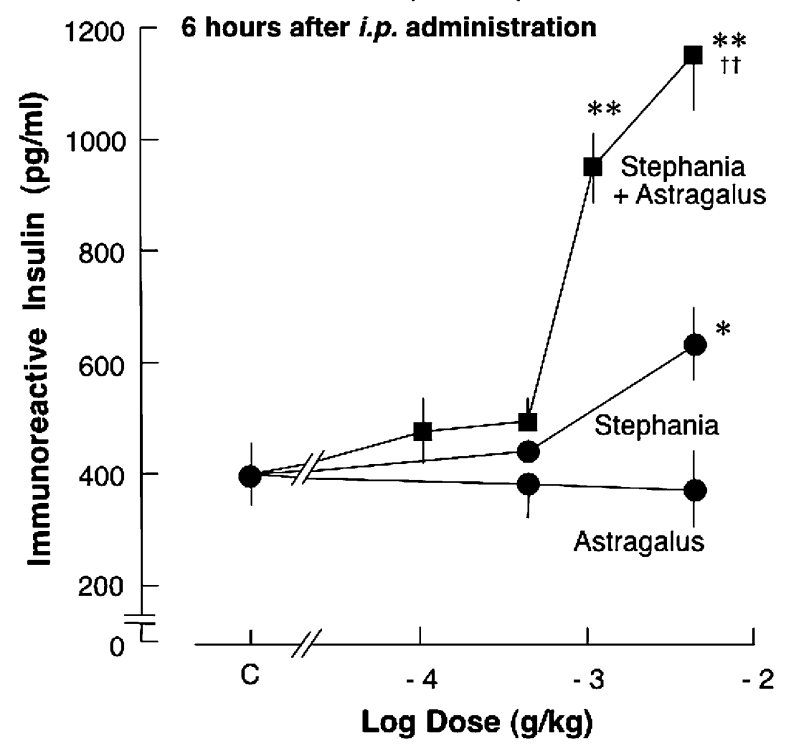

Fig. 2. Antihyperglycemic (A) and Insulinotropic (B) Acitivty of Extracts of Astragalus, Stephania, and Stephania in Combination with Astragalus (Stephania + Astragalus) in STZ-diabetic Mice

Blood glucose (A) and blood immunoreactive insulin (B) levels were measured before and $6 \mathrm{~h}$ after intraperitoneal administration of extracts of astragalus, stephania (O), and stephania with astragalus (1:3) ( $\mathbf{\square})$ to $14 \mathrm{~h}$-fasted diabetic mice. Values represent mean \pm S.E.M. of data from 6-14 (A) and 4-19 mice (B). Shadowed columns represent ranges of S.E.M. in data from 7 mice in saline alone (A). C; control saline group without drug. ${ }^{*} p<0.05$, ${ }^{* *} p<0.01$ versus the control group without drug. ${ }^{\dagger \dagger} p<0.01$ versus stephania extract alone. Reproduced, with permission, from Liu et al., 2000. ${ }^{2}$

A.

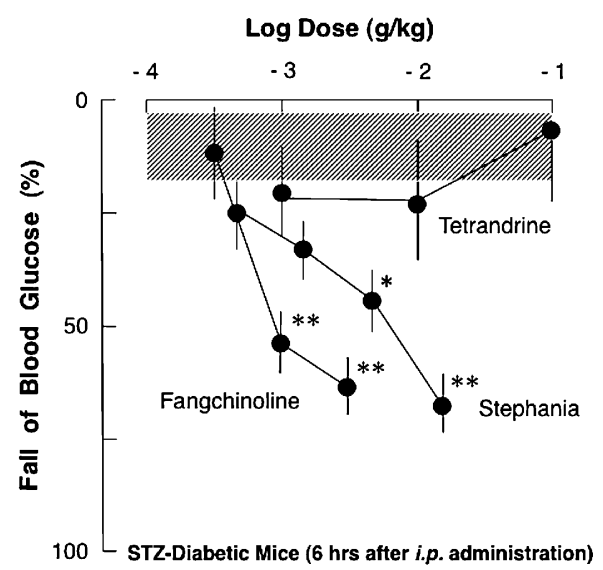

B.

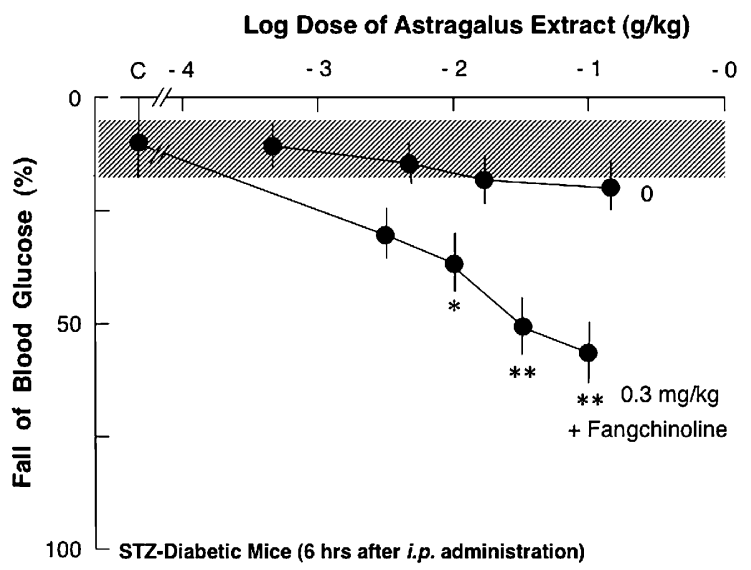

Fig. 3. Effects of Fangchinoline, Tetrandrine, and Stephania Extract (A) and Effects of Astragalus Extract Combined with Fangchinoline (B) on Blood Glucose Levels in STZ-diabetic Mice

Blood glucose levels were measured before and $6 \mathrm{~h}$ after intraperitoneal administration of the drugs (A), and astragalus extract and $0.3 \mathrm{mg} / \mathrm{kg}$ fangchinoline or astragalus extract alone (B) in diabetic mice. Values are expressed as mean \pm S.E.M. of data from 4-9 (A) and 6-15 mice (B). C; Fangchinoline (0.3 mg/kg) without astragalus extract. Shadowed column represents S.E.M. in the saline group. ${ }^{*} p<0.05$, ${ }^{* *} p<0.01$ versus the saline group (A) and ${ }^{*} p<0.05$, ${ }^{* *} p<0.01$ versus fangchinoline alone (B). Modified, with permission, from Tsutsumi et al., 2003') and Ma et al., 2007.4)

もう 1 つの主要成分 tetrandrine は全く効果を示さ なかつた [Fig. 3(A)]. その他の成分として cycleanine $ゃ$ tetrandrine $2^{\prime}-N$ - $\beta$-oxide, tetrandrine $2^{\prime}-N$ - $\alpha$-oxide, tetrandrine $2-N$ - $\beta$-oxide, fangchinoline $2^{\prime}-N$ - $\alpha$-oxide, $2^{\prime}-N$-norfangchinoline は血糖下 降作用を有したが， cycleanorine や cyclanoline， stephenanthrine は作用を示さなかった（Scheme 1 and Table 1). 4) 黄者成分 formononetin や calycosin (Scheme 2) が黄者エキスと同様に単独作用を示さ なかったが, fangchinoline と併用することにより， fangchinoline の血糖下降作用を有意に増強した [Figs. 3 (B) and 4]. Fangchinoline は insulin 分泌 も促進し， formononetin は fangchinoline の作用を 増強したことから，この粉防已と黄者間の複合作用 


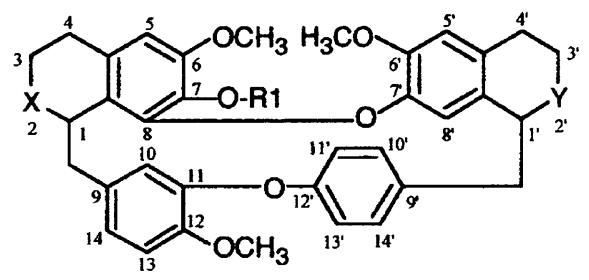

\begin{tabular}{|c|c|c|c|}
\hline Compounds & R1 & $x$ & $Y$ \\
\hline Fangchinoline & $H$ & $\mathrm{~N}-\mathrm{CH}_{3}$ & $\mathrm{~N}-\mathrm{CH}_{3}$ \\
\hline Tetrandrine & $\mathrm{CH}_{3}$ & $\mathrm{~N}-\mathrm{CH}_{3}$ & $\mathrm{~N}-\mathrm{CH}_{3}$ \\
\hline $\begin{array}{l}\text { Tetrandrine } 2 \text { - }-\mathrm{N} \text { - } \beta \text {-oxide } \\
\text { (TD-7) }\end{array}$ & $\mathrm{CH}_{3}$ & $\mathrm{~N}-\mathrm{CH}_{3}$ & $\underset{\mathrm{D}}{\mathrm{N} \cdots \mathrm{CH}_{3}}$ \\
\hline $\begin{array}{l}\text { Tetrandrine } 2^{\prime}-\mathrm{N} \text { - } \alpha \text {-oxide } \\
\text { (TD-11) }\end{array}$ & $\mathrm{CH}_{3}$ & $\mathrm{~N}-\mathrm{CH}_{3}$ & $\begin{array}{l}\mathrm{N}-\mathrm{CH}_{3} \\
\vdots \\
\vdots \\
0\end{array}$ \\
\hline $\begin{array}{l}\text { Tetrandrine 2-N- } \beta \text {-oxide } \\
\text { (TD-10) }\end{array}$ & $\mathrm{CH}_{3}$ & $\mathfrak{\downarrow}^{\mathrm{N} \cdots \mathrm{CH}_{3}}$ & $\mathrm{~N}-\mathrm{CH}_{3}$ \\
\hline $\begin{array}{l}\text { Fangchinoline } 2 \text { '- } \mathrm{N} \text { - } a \text {-oxide } \\
\text { (TD-8) }\end{array}$ & H & $\mathrm{N}-\mathrm{CH}_{3}$ & $\begin{array}{l}\underset{\mathrm{N}}{\grave{Y}}-\mathrm{CH}_{3} \\
\mathrm{O}\end{array}$ \\
\hline $\begin{array}{l}\text { 2'-N-Nortangchinoline } \\
\text { (TD-28) }\end{array}$ & $\mathrm{H}$ & $\mathrm{N}-\mathrm{CH}_{3}$ & NH \\
\hline $\begin{array}{l}\text { 2'-N-Methyttetrandrinium chloride } \\
\text { (TD-13) }\end{array}$ & $\mathrm{CH}_{3}$ & $\mathrm{~N}-\mathrm{CH}_{3}$ & $\begin{array}{l}\mathrm{N}^{+} \mathrm{Cl}^{-} \mathrm{CH}_{3} \\
\mathrm{CH}_{3}\end{array}$ \\
\hline Cycleanorine & $\mathrm{CH}_{3}$ & $\mathrm{~N}-\mathrm{CH}_{3}$ & NH \\
\hline
\end{tabular}

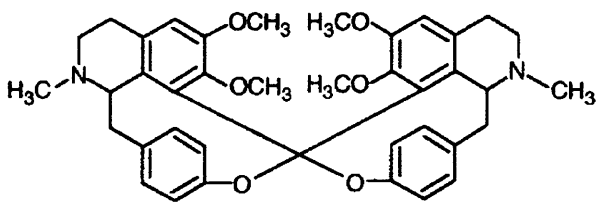

Cycleanine (TD-14)<smiles>COc1cc2c(cc1O)C1Cc3ccc(OC)c(O)c3C[N+]1(Cl)CC2Cl</smiles>

Cyclanoline chloride

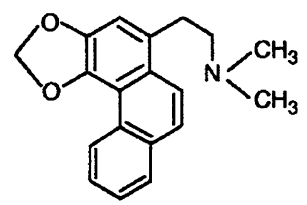

Stephenanthrine

Scheme 1. Chemical Structures of Alkaloids Isolated from Stephania Used in Experiments Reproduced, with permission, from Tsutsumi et al., 2003.3)

Table 1. Effects of Compounds Isolated from Stephania on Blood Glucose Levels in Diabetic Mice

\begin{tabular}{lrc}
\hline \hline \multirow{1}{*}{ Drug } & $n$ & Decrease in blood glucose \\
\cline { 3 - 3 } & & $(\%)$ \\
\hline Saline & 13 & $10.9 \pm 7.7$ \\
Tetrandrine & 5 & $22.2 \pm 11.3$ \\
TD-7 & 4 & $53.5 \pm 15.5^{*}$ \\
TD-11 & 4 & $59.0 \pm 10.7^{* *}$ \\
TD-10 & 7 & $48.2 \pm 7.2^{* *}$ \\
TD-13 & 4 & $7.5 \pm 10.1$ \\
Cycleanorine & 6 & $20.2 \pm 11.8$ \\
Fangchinoline & 7 & $52.7 \pm 6.7^{* *}$ \\
TD-8 & 4 & $50.7 \pm 14.5^{*}$ \\
TD-28 & 5 & $40.3 \pm 11.1^{*}$ \\
Cycleanine & 6 & $50.1 \pm 9.0^{* *}$ \\
Cyclanoline & 7 & $24.0 \pm 8.8$ \\
Stephenanthrine & 7 & $7.4 \pm 15.4$ \\
\hline
\end{tabular}

The decrease (\%) in blood glucose was calculated based on glucose levels before and after the administration of the test drug $(1 \mathrm{mg} / \mathrm{kg})$ or saline in $14 \mathrm{~h}$-fasted diabetic mice. Values are expressed as mean \pm S.E.M. of data from 3-13 animals. $n$ represents number of data. ${ }^{*} p<0.05,{ }^{* *} p<$ 0.01 versus the value of saline in the unpaired $t$-test. Reproduced, with permission, from Tsutsumi et al., 2003.3)
を fangchinoline と formononetin の成分レベルでも

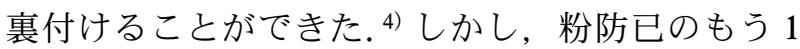
つの主要成分である tetrandrine は, fangchinoline と構造が類似しているが，血糖降下作用を示さな かった.

\section{STZ-糖尿病態ラットの脈絡膜の新生血管増} 生に対する粉防已やその成分の抑制効果

糖尿病合併症の 1 つである糖尿病性網膜症の病因 として, 糖尿病態の網膜や脈絡膜組織中に蓄積する advanced glycation endproducts（AGEs）が注目さ れている. ${ }^{5)}$ 筆者らは STZ-糖尿病態ラットの脈絡膜 組織において AGEs の 1 つである $N^{\varepsilon_{-}}$( carboxymethyl) lysine (CML) が蓄積し, 脈絡膜の新生血 管を異常増生させることを抗 CML モノクローナル 抗体 (6D12)6) を用いて明らかにした (Fig. 5).7) $\mathrm{STZ}$ 投与 4 週間後（糖尿病態初期）と 8 力月後 (糖尿病態方進期) のラットを用いて，糖尿病態経 過による脈絡膜血管新生異常を比較すると，糖尿病 態が進行するにつれて脈絡膜の新生血管が著しく増 生した（Fig. 6)。この異常増生は, 糖尿病態元進 


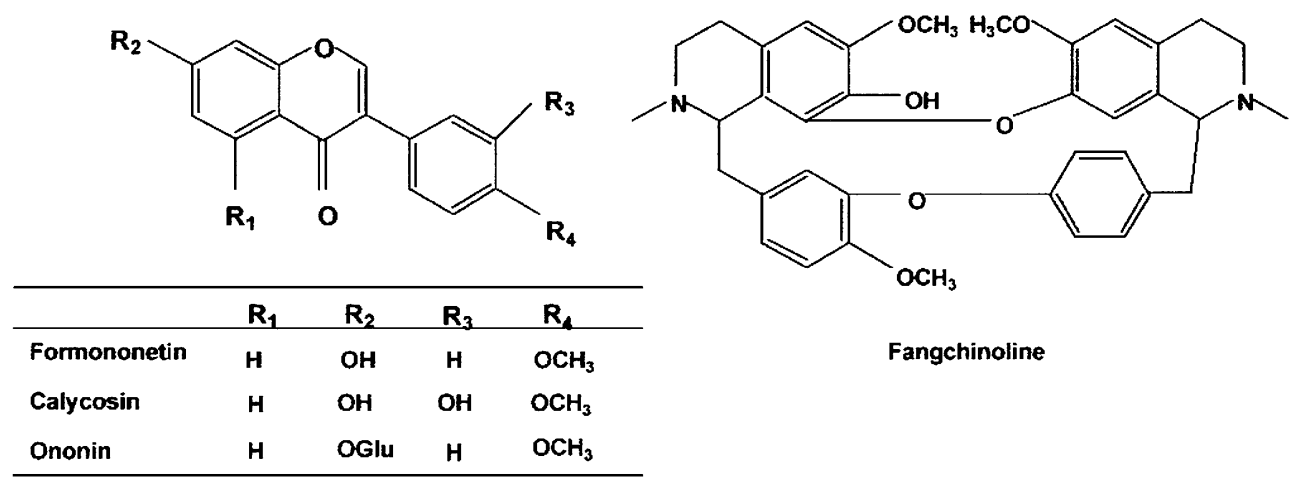

Scheme 2. Chemical Structures of Formononetin, Calycosin, Ononin, and Fangchinoline Reproduced, with permission, from Ma et al., 2007.4)

A.

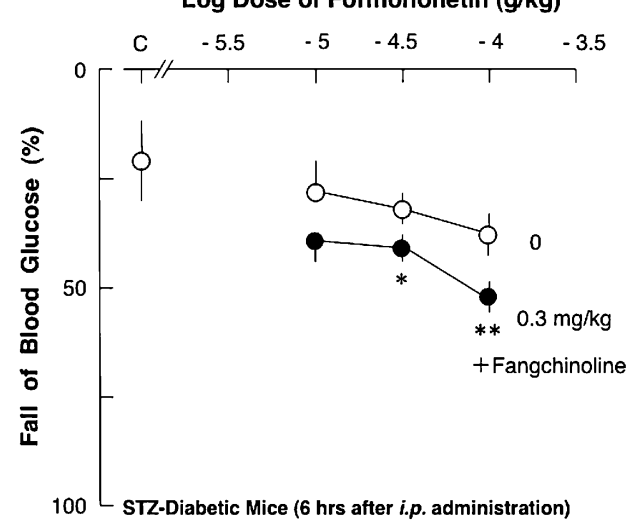

B.

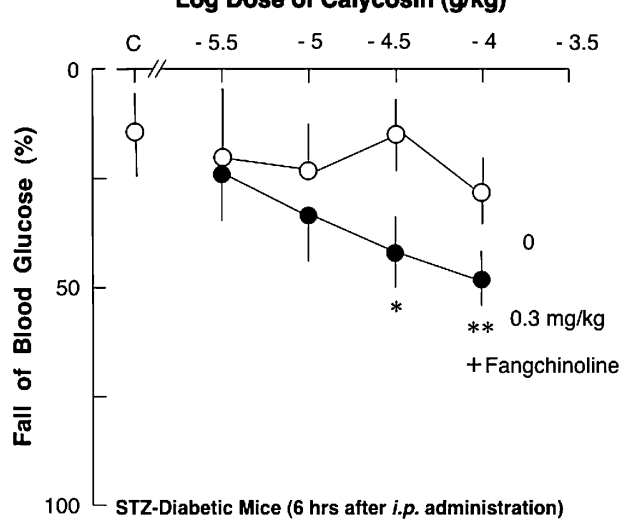

Fig. 4. Combined Effects of Formononetin with Fangchinoline (A) and Calycosin with Fangchinoline (B) on Blood Glucose Levels in Diabetic Mice

Blood glucose levels were measured before and $6 \mathrm{~h}$ after administration of formononetin and $0.3 \mathrm{mg} / \mathrm{kg}$ fangchinoline $(\boldsymbol{O})$, formononetin alone $(\mathrm{O})$, and saline $(\mathrm{C} ; \mathrm{O})(\mathrm{A})$, and calycosin and $0.3 \mathrm{mg} / \mathrm{kg}$ fangchinoline $(\mathbf{O})$, calycosin alone $(\mathrm{O})$, and saline $(\mathrm{C} ; \mathrm{O})(\mathrm{B})$ into $3 \mathrm{~h}$-fasted diabetic mice. Values are expressed as mean \pm S.E.M. of data from $6-15$ mice. ${ }^{*} p<0.05,{ }^{* *} p<0.01$ versus the saline group without drug (C). Modified, with permission, from Ma et al., 2007.4)

期ばかりでなく加齢ラットにおいてもみられた [Fig. 6(B) ]. ${ }^{8)}$ 糖尿病態充進期や加齢期による血管 新生異常が 6D12 により特異的に抑制されたこと [Figs. 6(C) and (D) ] から, 糖尿病態六進期や加 齢期の脈絡膜に蓄積した CML が新生血管を異常に 増生することを明らかにした。同様な現象が加齢 ラットの海馬の脈絡叢においてもみられた。CML が加齢ラットの脈絡叢に蓄積して, 培養海馬の新生 血管を異常増生した。CML による海馬の血管新生 異常と認知症誘発との関連が注目されているので, 眼底検査による網膜血管の観察が網膜症予防ばかり でなく認知症予防にもつながる可能性を推察でき た. ${ }^{9,10)}$

糖尿病態組織に蓄積した CML と血管新生因子の 生成や活性との関連を検討した。糖尿病態初期ラッ トの培養脈絡膜組織は tumor necrosis factor (TNF)
- $\alpha$ の生成に促進傾向を示した。培養液に投与した 外来性の CML は, 糖尿病態初期の培養脈絡膜の $\mathrm{TNF}-\alpha$ 生成を培養正常脈絡膜より強力に促進した [Fig. 7(A) ]. ${ }^{8)}$ さらに, 加齢期の培養脈絡膜は, 糖 尿病態初期より著しく TNF- $\alpha$ 生成を促進した [Fig. 7 (B) ]. 次に, 糖尿病態初期の培養脈絡膜は 培養正常脈絡膜より vascular endothelial growth factor（VEGF）生成を促進し，外来性の CML は糖尿 病態初期脈絡膜組織の VEGF 生成を著しく増強し た [Fig. 7(A)]。加齢期の培養脈絡膜も VEGF 生 成を促進したが，その生成量は，糖尿病初期に比べ て少なかった [Fig. 7(B)]。また，外来性の CML は糖尿病態初期の培養脈絡膜の platelet derived growth factor（PDGF）-B 生成をわずかに増加した が，正常脈絡膜に対しては作用を示さなかつた [Fig. 7 (A) ]. 加齢期の培養脈絡膜は, 糖尿病態初 

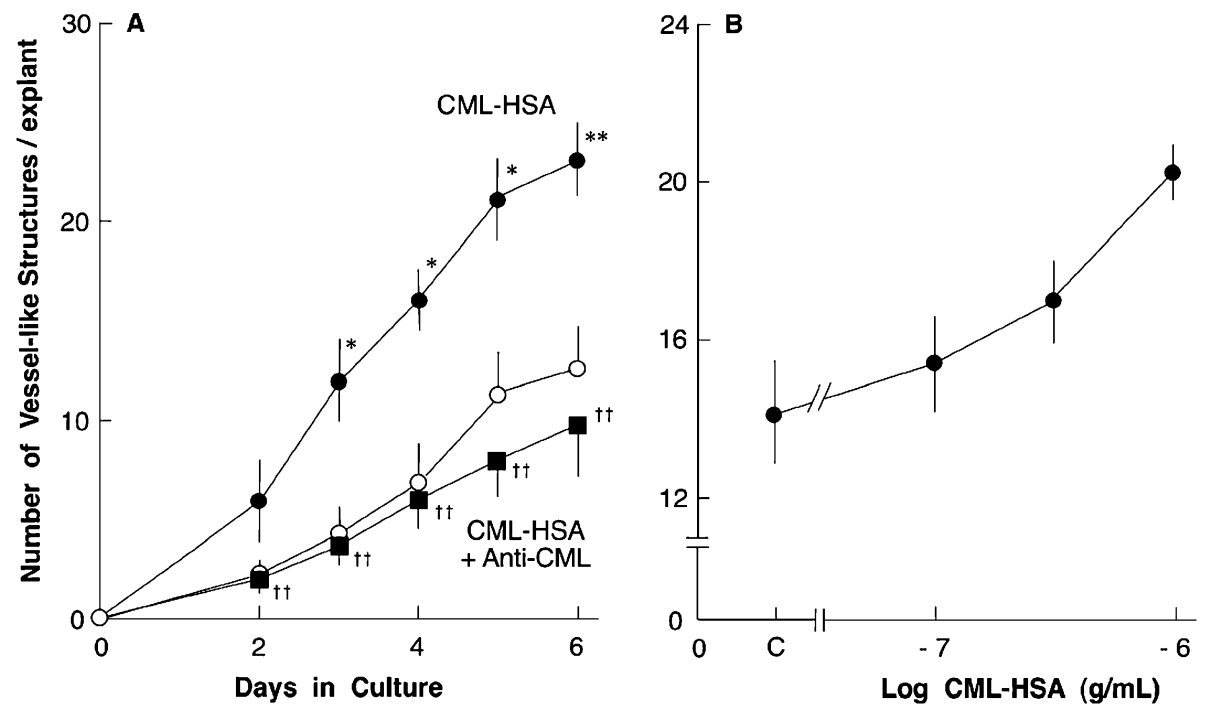

Fig. 5. Effects of Anti- $N^{\varepsilon}$ - (carboxymethyl) lysine (CML) Antibody on CML-Human Serum Albumin (HSA) -induced Increase in the Number of Vessel-like Structures (A) and Concentration-dependent Action of CML-HSA on Number of Vessel-like Structures (B) Budded from Cultured Rat Choroidal Explants

Explants were cultured in fibrin gel in the presence of $1 \%$ fetal bovine serum (FBS) (A; O), $1 \%$ FBS with $1 \mu \mathrm{g} / \mathrm{mL} \mathrm{CML-HSA}$ (A; ), and various concentrations of CML-HSA $(\mathrm{B} ;$ ) and $1 \%$ FBS with $1 \mu \mathrm{g} / \mathrm{mL}$ CML-HSA and $3 \mu \mathrm{g} / \mathrm{mL}$ anti-CML antibody $(\mathrm{A} ; \boldsymbol{\square})$ for $6 \mathrm{~d}$. The number of vessel-like structures in choroidal explants was counted on 0-6 d (A) and $6 \mathrm{~d}$ (B) in culture. Values represent mean \pm S.E.M. of 12-14 data (A) and 6-10 data (B). C represents control value without CML-HSA (B). ${ }^{*} p<0.05,{ }^{* *} p<0.01$ versus control without CML-HSA on the corresponding days in culture. ${ }^{\text {tt}} p<0.01$ versus the corresponding value with CML-HSA. Reproduced, with permission, from Kobayashi et al., 2004.7)

\section{Choroid}

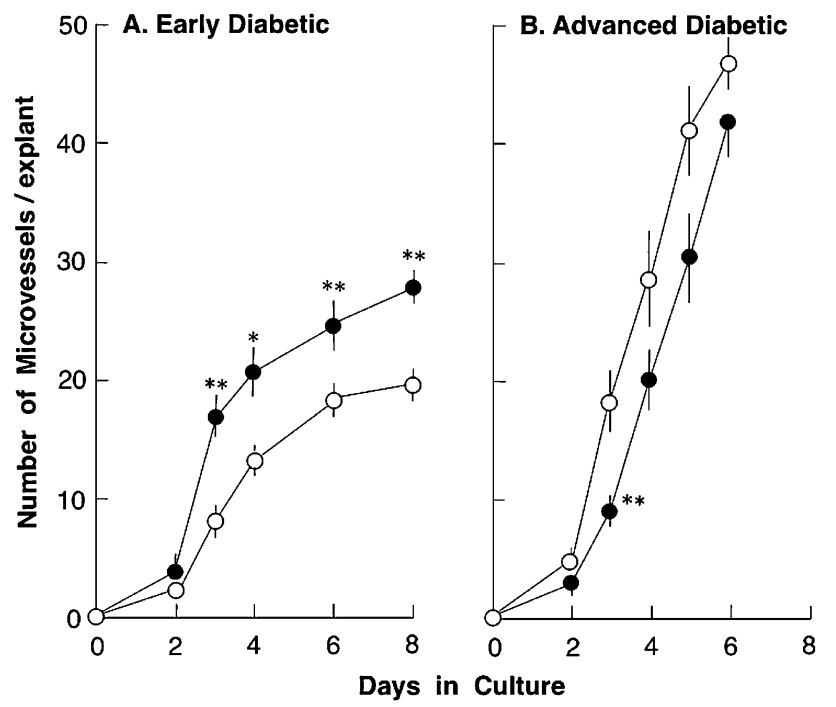

Anti-CML (Choroid)

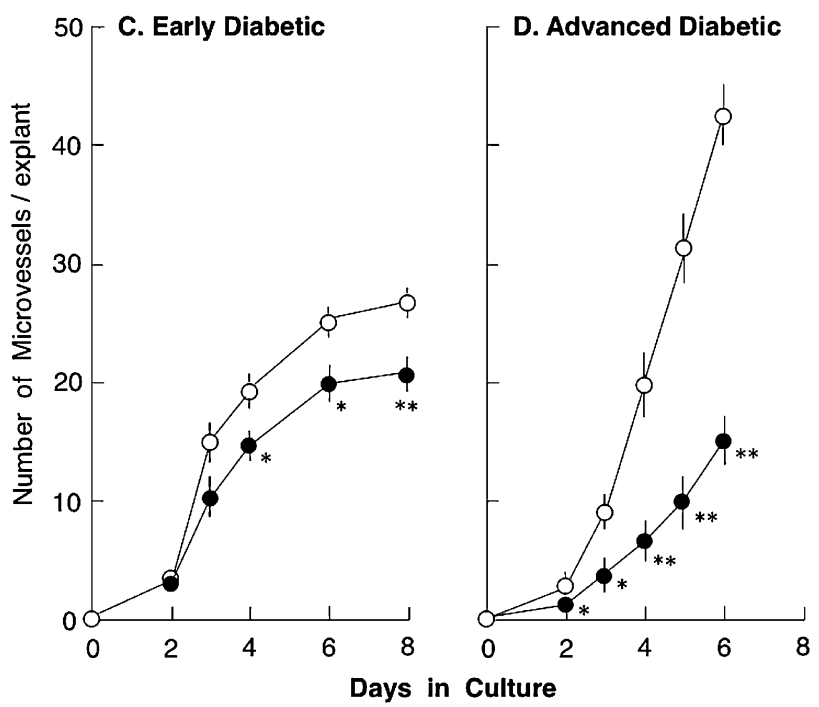

Fig. 6. Neovascular Activity of Choroidal Explants in the Early Stage (A) and Advanced Stage (B) of STZ-diabetic Rats and Inhibitory Effects of Anti-CML Antibody on the Increase in the Number of Microvessels in the Early Stage (C) and Advanced Stage (D) in STZ-diabetic Rats

Choroidal explants from early-diabetic rats $(\mathrm{A} ; \mathbf{O})$ and age-matched young normal rats $(\mathrm{A} ; \mathrm{O})$ and advanced-diabetic rats $(\mathrm{B} ; \mathbf{O})$ and age-matched aged normal rats $(\mathrm{B}$; $\mathrm{O})$ were cultured in fibrin gel with 5\% FBS-DMEM for 2-8 d. Choroidal explants from early-diabetic rats (C) and advanced-diabetic rats (D) were cultured in fibrin gel with $5 \%$ FBS-DMEM in the presence $(O)$ or absence $(\mathrm{O})$ of anti-CML antibody $(3 \mu \mathrm{g} / \mathrm{mL})$ for $2-8$ or $2-6 \mathrm{~d}$. Values are expressed as mean \pm S.E.M. of 8-15 data (A, B) and 10-30 data (C, D). ${ }^{*} p<0.05,{ }^{* *} p<0.01$ versus normal values (A, B) and values without antibody (C, D) on the corresponding day in culture. Modified, with permission, from Kobayashi et al., 2004. ${ }^{8)}$ 

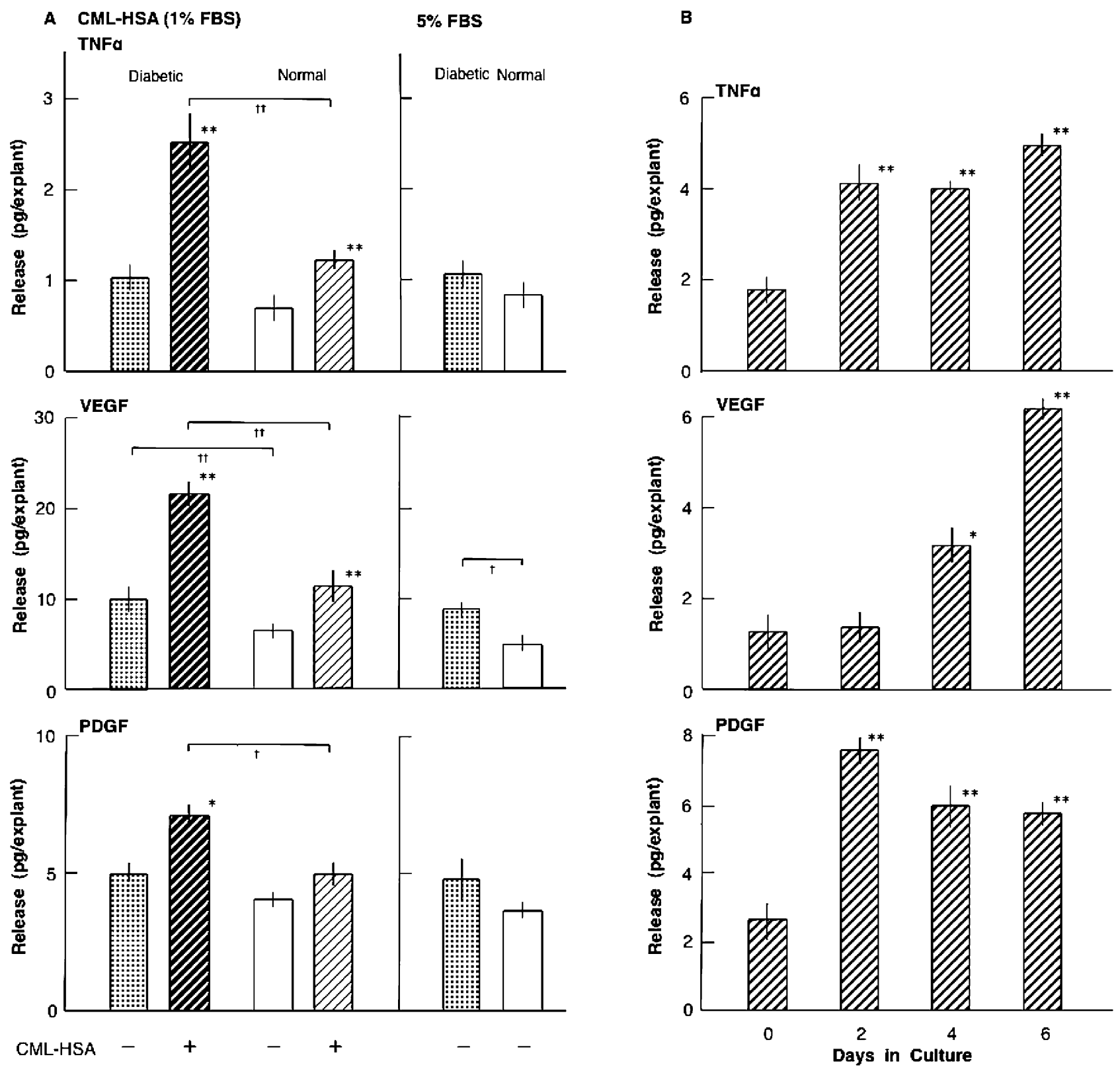

Fig. 7. TNF- $\alpha$, VEGF, and PDGF-B Released from CML-HSA-treated Choroidal Explants of Early-diabetic and Age-matched Normal Rats (A) and aged Normal Rats (B)

Choroidal explants were cultured in fibrin gel with $1 \%$ FBS-DMEM in the presence or absence of CML-HSA $(1 \mu \mathrm{g} / \mathrm{mL})(\mathrm{A}$, left) and with $5 \%$ FBS-DMEM (A, right) for $6 \mathrm{~d}$. Levels of TNF- $\alpha$, VEGF, and PDGF-B were measured in culture media during days 4-6 in culture (A) and in culture media during days $0-2,2-4$, and 4-6 in culture using ELISA kits (B). Values represent mean \pm S.E.M. of 7-20 data (A) and 6-12 data (B). ${ }^{*} P<0.05$, ${ }^{* *} P<0.01$ versus the values in the diabetic and normal choroids without CML-HSA (A) ${ }^{\dagger} p<0.05,{ }^{\dagger+} p<0.01$ versus the value in the normal choroid (A). ${ }^{*} p<0.05,{ }^{* *} p<0.01$ versus the corresponding value in media without explants (day 0) (B). Modified, with permission, from Kobayashi et al., 20048) and Kobayashi et al., 2007. ${ }^{11)}$

期と比較して PDGF-B 生成を著しく促進した [Fig. 7(B) ]. ${ }^{11)}$ 以上から，糖尿病態期や加齢期の脈 絡膜組織が CML を蓄積して，TNF- $\alpha$ や VEGF, PDGF-B の生成と作用を介して，新生血管を異常 増生することを明らかにした。

粉防已エキスが，糖尿病態初期による培養脈絡膜 の血管新生作用を同週齢の正常組織に比べて強力に 抑制した。 ${ }^{12)}$ Tetrandrine も，この糖尿病態による
脈絡膜の血管新生作用を正常組織より著しく抑制し たので，粉防已の抗血管新生作用を少なくとも tetrandrine が担っていることを裏付けた. ${ }^{13)}$ Tetrandrine の構造類似化合物を用いて抗血管新生作用の 構造活性相関を検討した。類似化合物 KS-1-4 と KS-1-1 はいずれも tetrandrine と同様に強力な抗血 管新生作用を有したが, ${ }^{13)} \mathrm{KS}-1-4$ は，KS-1-1 とは 異なり，正常マウスの脈絡膜の血管新生を抑制せ 


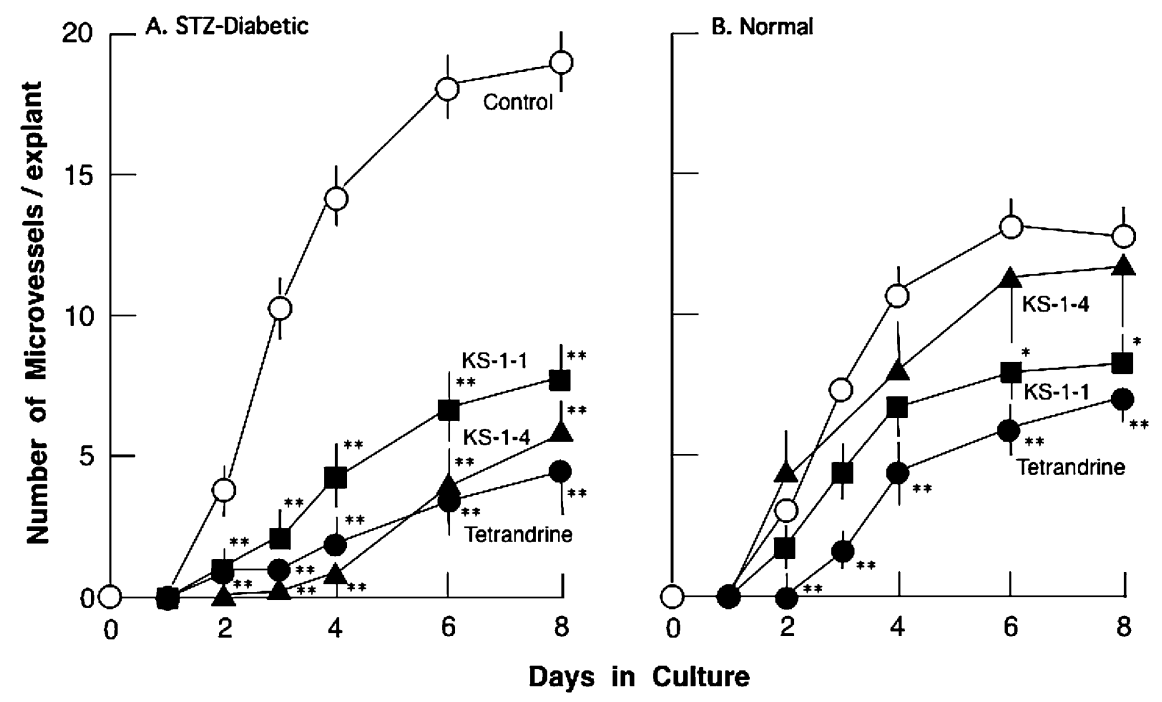

Fig. 8. Time-dependent Inhibitory Effects of Tetrandrine, KS-1-1, and KS-1-4 on Choroidal Angiogenesis in STZ-diabetic (A) and Age-matched Normal Rats (B)

Choroidal explants were cultured with 5\% FBS-DMEM in fibrin gel in the presence or absence $(\bigcirc)$ of KS-1-1 ( $\mathbf{\square})$, KS-1-4 $(\mathbf{\Delta})$, and tetrandrine $(\mathbf{O})(1 \mu \mathrm{M})$ for 8 d. Values are expressed as mean \pm S.E.M. of $11-16$ data. ${ }^{*} p<0.05,{ }^{* *} p<0.01$ versus the corresponding control without drug. Reproduced, with permission, from Kobayashi et al., 1999.13)

ず，糖尿病態初期の脈絡膜の血管新生を選択的に抑 制した (Fig. 8)。粉防已成分 cycleanine は血糖下 降作用を有することを上記したが，抗血管新生作用 がないことから, ${ }^{13)}$ tetrandrine の血管新生抑制作 用機序は，cycleanine や fangchinoline の血糖下降 作用機序と異なることを裏付けた。KS-1-4 や tetrandrine は，VEGF や PDGF-B による脈絡膜血 管新生作用も特異的に抑制したが，KS-1-1 は，こ れらの血管新生作用を抑制しなかった. ${ }^{13)} \mathrm{CML}$ は 糖尿病態の脈絡膜において, TNF- $\alpha$ や PDGF-B, VEGF の生成を促進するので, KS-1-4 や tetrandrine は，CMLやこれら血管新生因子に対する抗 血管新生作用を介して，脈絡膜血管新生異常を抑制 することを明らかにした.

TNF- $\alpha$ の血管新生作用に対する tetrandrine の抑 制作用機序を検討した。 tetrandrine は TNF- $\alpha$ によ る脈絡膜血管新生作用を特異的に抑制した。

Tetrandrine の抗血管新生作用は, nuclear factor $(\mathrm{NF})-\kappa \mathrm{B}$ 阻害剤である ammonium pyrrolidine dithiocarbamate (APDC) の抗血管新生作用 ${ }^{14)}$ と類 似していた（Fig. 9)。したがって, tetrandrineは, TNF- $\alpha$ による脈絡膜の NF- $\kappa$ B 活性化作用を抑制し て抗血管新生作用を誘導することが考えられた。 TNF- $\alpha$ は，脈絡膜細胞の細胞質内の $\operatorname{IkB} \alpha$ 量の減少 とリン酸化 $\mathrm{IkB} \alpha$ 量の増加を導き，核内においては
NF- $\kappa \mathrm{B}$ の DNA 結合活性を促進した. ${ }^{15)}$ Tetrandrine は, $\mathrm{TNF}-\alpha$ による $\mathrm{I} \kappa \mathrm{B} \alpha$ 量の減少とリン酸化 $\mathrm{I} \kappa \mathrm{B} \alpha$ 量の増加と TNF- $\alpha$ による NF- $\kappa \mathrm{B}$ の DNA 結合活性 をそれぞれ特異的に抑制した. ${ }^{15)}$ さらに，TNF- $\alpha$ の 血管新生作用は，抗 VEGF 抗体により抑制され，

TNF- $\alpha$ は VEGF-A の mRNA 発現を促進したこと から，TNF- $\alpha$ は，VEGF-A の産生を介して，脈絡 膜血管新生を促進することを明らかにした. ${ }^{15)}$ 以上 から, tetrandrine の抗血管新生作用機序は, $\mathrm{TNF}-\alpha$ による一連の血管新生作用を抑制することで説明で きた.

4. STZ-糖尿病態マウスの血清パラメータに対 する防風通聖散の効果

漢方医学において, 湿証を適応症とする方剂のう ち，防已黄者湯は虚証に有効であるが，防風通聖散 は実証に有効であると言われている。防風通聖散 は, 山栃子と麻黄, 甘草, 大黄, 蓮趣, 芒硝, 生 姜, 荊芥, 桔梗, 防風, 川芦, 当帰, 苟薬, 白术, 薄荷, 黄芩, 滑石, 石膏の 18 生薬から構成されて いる。そこで，STZ-糖尿病態マウスにおける，防 風通聖散エキスの血糖下降作用機序を防已黄者湯工 キスと比較した。その結果, 防風通聖散エキスは, 防已黄耆湯エキスと同様に，絶食下で腹腔内投与に より, 高血糖值を低下させ, insulin 分泌を促進し た。この作用は，代表的血糖降下薬 glibenclamide 

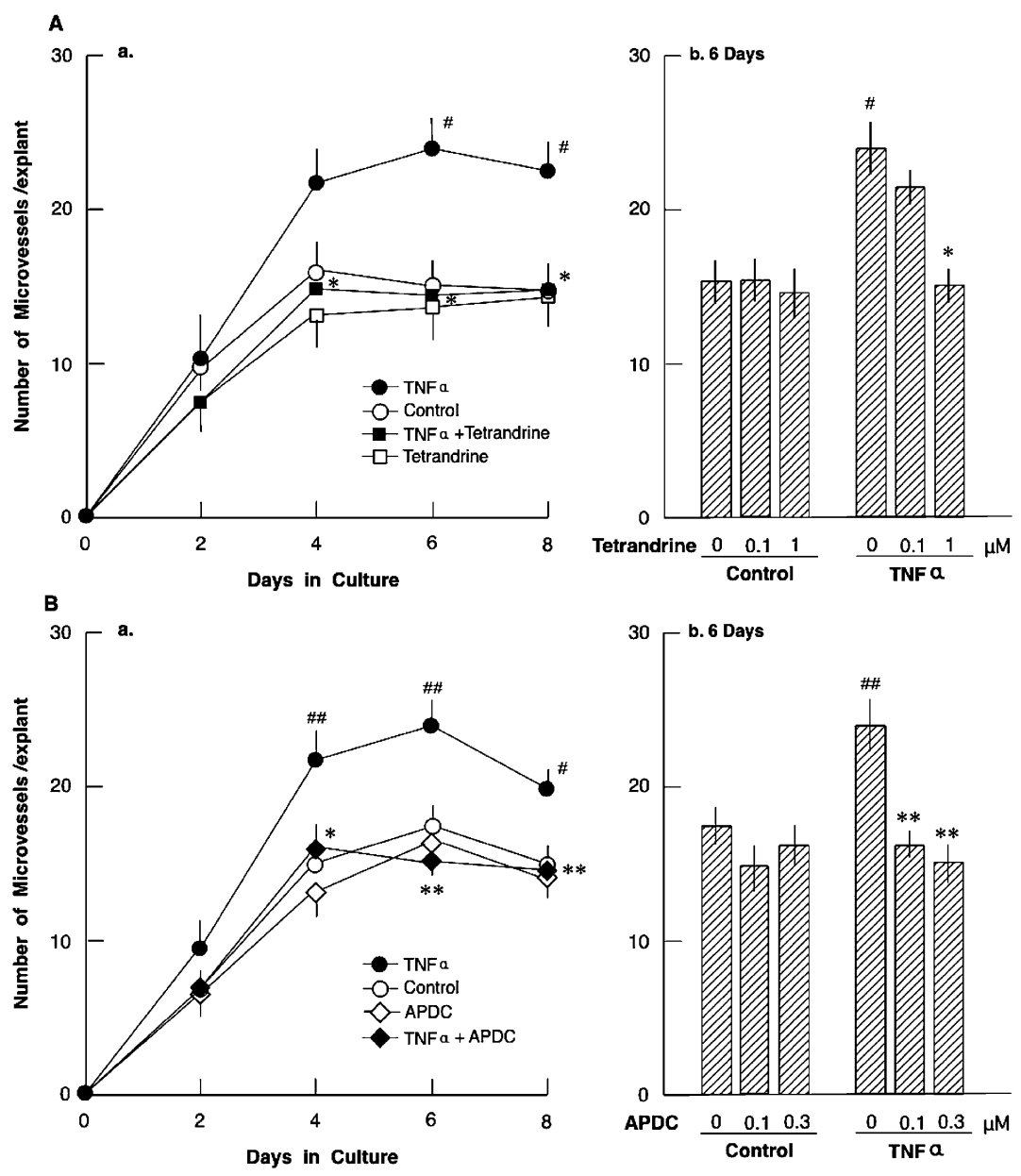

Fig. 9. Effects of Tetrandrine (A) and APDC (B) on the Increase in the Number of Microvessels Induced by TNF- $\alpha$ in Rat Choroidal Explants

Choroidal explants were cultured in the presence or absence of $10 \mathrm{ng} / \mathrm{mL}$ TNF- $\alpha$ with/without tetrandrine $(1 \mu \mathrm{M} ; \mathrm{A})$, or with/without APDC (0.3 $\mu \mathrm{M}$; B) for 8 d (a). The explants were cultured with tetrandrine $(0,0.1$, and $1 \mu \mathrm{M} ; \mathrm{A})$ or APDC $(0,0.1$, and $0.3 \mu \mathrm{M} ; \mathrm{B})$ in the presence (right) or absence (left) of $10 \mathrm{ng} / \mathrm{mL}$ TNF- $\alpha$ on day 6 of culture (b). Values are expressed as mean \pm S.E.M. of data from at least 3 rat explants. ${ }^{\sharp} p<0.05$ versus the corresponding control without TNF- $\alpha$ and without tetrandrine (A) . ${ }^{*} p<0.05$ versus TNF- $\alpha$ alone without tetrandrine (A). ${ }^{*} p<0.05,{ }^{*} p<0.01$ versus the corresponding control without TNF- $\alpha$ and without APDC. ${ }^{*} p<0.05,{ }^{* *} p<0.01$ versus TNF- $\alpha$ alone without APDC (B). Modified, with permission, from Kikuchi et al., 2010. ${ }^{15)}$
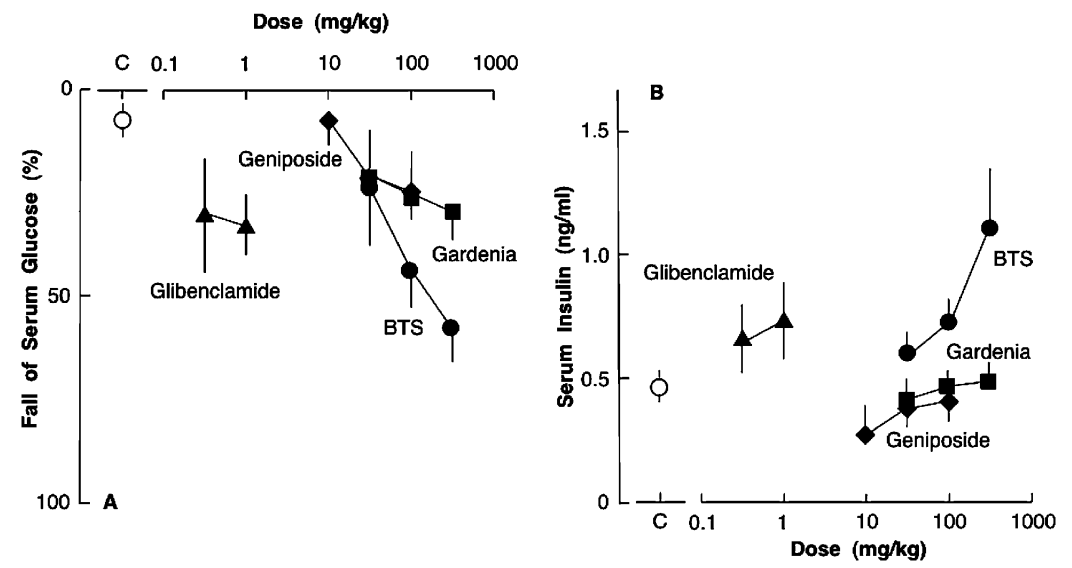

Fig. 10. Effects of Bofutsushosan (BTS) Extract, Glibenclamide, Gardenia Extract, and Geniposide on Serum Glucose (A) and Serum Insulin (B) Levels in STZ-diabetic Mice

Serum glucose levels (A) and serum immunoreactive insulin levels (B) were measured before and $6 \mathrm{~h}$ after i.p. administration of BTS extract (), Glibenclamide $(\boldsymbol{\Lambda})$, Gardenia extract $(\boldsymbol{\square})$, or Geniposide $(\bullet)$ to $3 \mathrm{~h}$-fasted diabetic mice. C; the water group without drug $(\mathrm{O})$. Values are expressed as mean \pm S.E.M. of data from 5-25 mice. Modified, with permission, from Yu et al., 2011.16) 

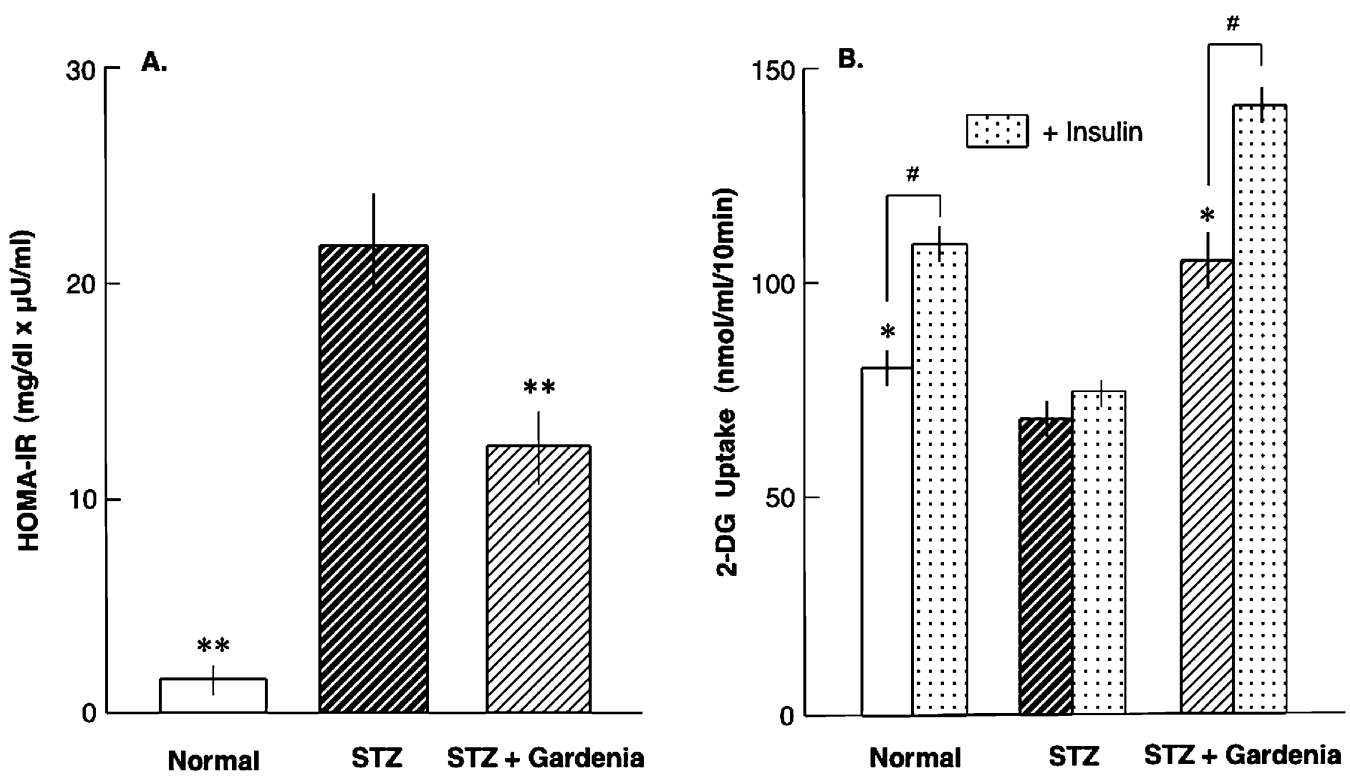

Fig. 11. Effects of Gardenia Extract on HOMA-IR Values in STZ-diabetic Mice (A) and on 2-deoxyglucose (DG) Uptake by the Soleus Muscle in STZ-diabetic Mice (B)

HOMA-IR values were calculated by following formula: fasting glucose $(\mathrm{mg} / \mathrm{dL}) \times$ fasting insulin $(\mu \mathrm{U} / \mathrm{mL}) / 405(A)$. Soleus muscles were incubated for 10 $\min$ in 2-DG solution with or without $10 \mathrm{nmol} / \mathrm{mL}$ insulin, and 2-DG uptake was normalized to tissue weight (B). Values represent mean \pm S.E.M. of data from 422 (A) or 3 mice (B). ${ }^{* *} p<0.01$ versus STZ-diabetic mice (A). ${ }^{*} p<0.05$ versus STZ-diabetic mice (B) . ${ }^{*} p<0.05$ versus without insulin (B). Modified, with permission, from Yu et al., 2013.18)

と類似していた（Fig. 10）.16）防風通聖散の構成生 薬の山栃子のエキスは，高血糖值を低下させたが, 血中 insulin 分泌作用を示さなかった。山栃子の主 要成分 geniposide も，血糖值を低下させたが，血 中 insulin 值を増加しなかったことから，山柧子エ キスの血糖降下作用が成分レベルでも裏付けられた (Fig. 10)。他方，防風通聖散エキスは，血中 triglyceride や cholesterol 值も低下させたが, glibenclamide はこれらに対して作用が弱いかほと んどみられなかったことから，糖尿病態における防 風通聖散エキスの血糖降下作用機序は，血中 triglyceride や cholesterol の低下作用と直接関連し ていないと考えられた。 ${ }^{16)}$ 山秨子エキスは，防風通 聖散エキスと同様に血中 triglyceride 值と cholesterol 值を減少させた。しかし，geniposide は，血中 triglyceride 值や cholesterol 值を低下させ なかったことから，山柧子エキスによるこれらの低 下作用機序には, geniposide とは異なる山栃子成分 が役割を担っている可能性が考えられた. ${ }^{16)}$ 山暦子 以外では，麻黄や防風，荊芥，蓮趐，黄芩，石膏は 単味で血糖下降作用と insulin 分泌作用を有し，莐

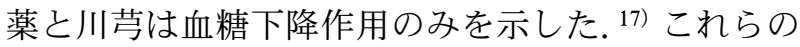
構成生薬が，方剂の中で総合的に作用して，抗糖尿
病作用を導くと考えられるが，この作用を解明する ために，更なる詳細な研究が必要である.

STZ-糖尿病態マウスは, insulin 抵抗性の指標で ある HOMA-IR 值を増大し，骨格筋の 2-deoxyglucose（DG）の取り込夕に対する insulin 感受性を低 下した（Fig. 11）. 18) 山栃子エキスは，この糖尿病 態の HOMA-IR 值を有意に低下させ，骨格筋の 2-DG 取り込みを約 1.5 倍増加させた。さらに, 2-DG 取り込みに対する insulin 感受性を正常マウ スのレベルまで回復させた（Fig. 11）。山栀子エキ 又は，糖尿病態の骨格筋細胞膜画分の糖輸送担体 （Glut）4レベルを増加し，細胞質画分のリン酸化 Akt 值を増加させた. ${ }^{18)}$ 以上から，山秨子エキスの 作用機序は，糖尿病態の骨格筋細胞における Akt リン酸化を介して細胞膜への Glut4 の移行を促進し て, insulin 抵抗性を改善すると結論できた.

\section{5. 高脂肪食摂取 STZ-糖尿病態マウスの血清パ} ラメータに対する山栃子の効果

高脂肪食摂取 STZ-糖尿病態マウスは STZ-糖尿病 態マウスよりも II 型糖尿病態モデルとして繁用され

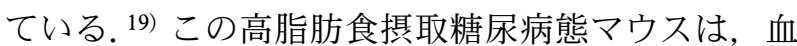
中 TNF- $\alpha$ 量や leptin 量, 遊離脂肪酸量をいずれも 正常マウスと比較してそれぞれ 6 倍及び 2 倍， 2 倍 

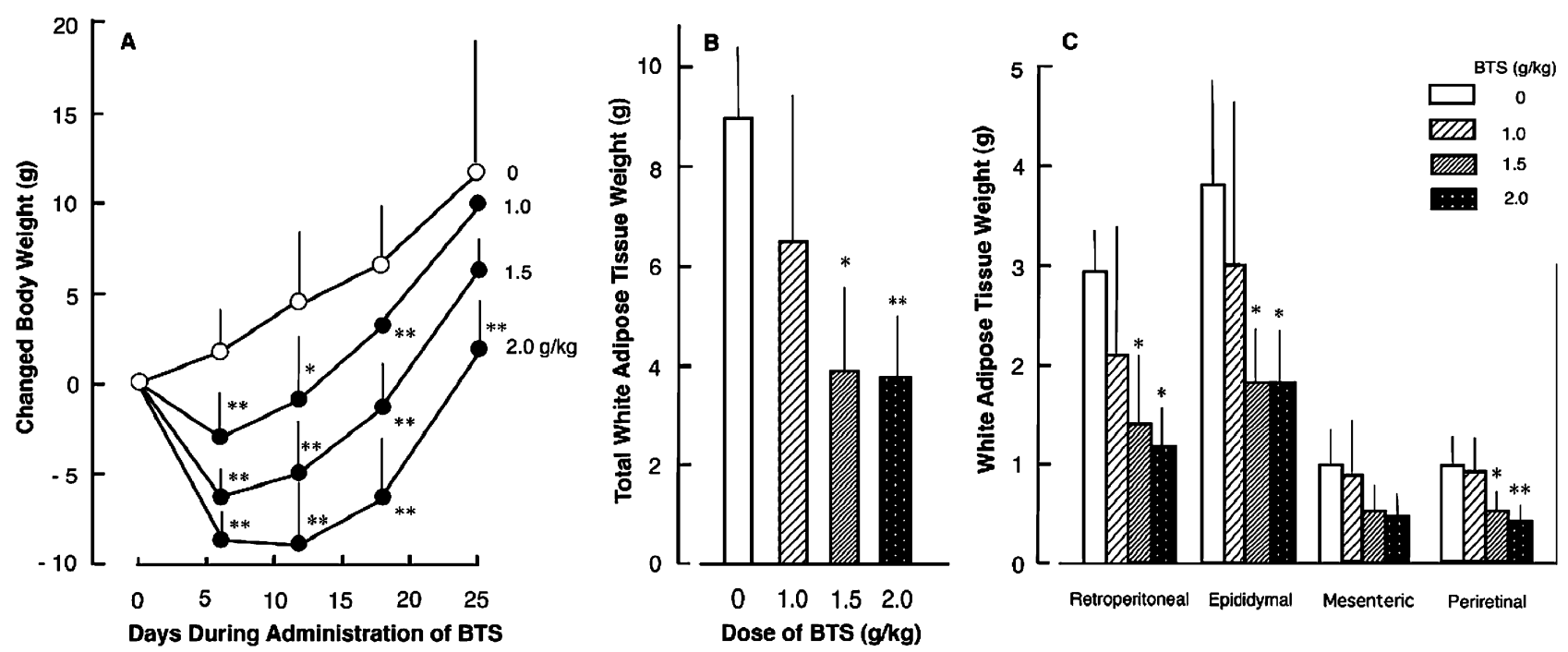

Fig. 12. Effects of BTS Extract on Body Weight (A), Total White Adipose Tissue Wet Weight (B), and Individual Wet Weights of Retroperitoneal, Epididymal, Mesenteric, and Periretinal White Adipose Tissues (C) in Obese Mice at 9 Weeks of Age Orally Administered Various Drug Doses $(0,1.0,1.5$, and $2.0 \mathrm{~g} / \mathrm{kg}$ ) for 25 Days While Fed a HFD

ICR mice (4 weeks of age) were provided the HFD for 5 weeks ad libitum. Body weights were measured on days $0,6,12,18$, and 25 of administration. Body weight changes were calculated from day 0 before administration of BTS extract to day 25 (A). White adipose tissues were isolated from obese mice and wet weights measured (B, C). Values are expressed as mean \pm S.D. ( $n=5-8$ mice). Differences between group means were evaluated by Tukey's or Scheffe's test. ${ }^{*} p<0.05,{ }^{* *} p$ $<0.01$ versus control water group without BTS extract. Modified, with permission from Kobayashi et al., 2017.21)

増加した．山栃子エキスは，経口投与により高脂肪 食摂取糖尿病態マウスの高血糖值の低下と血中 insulin 值の増加を介して, insulin 抵抗性を低下させ た。また，山桅子エキスは，血中 triglyceride 值と 血中 cholesterol 值も減少させた. ${ }^{20)}$ 山栃子エキス は，投与 2 週間後から血中 TNF- $\alpha$ 量や leptin 量を 有意に低下させ，投与 3 週間では遊離脂肪酸量も有 意に低下させ，血中 adiponectin 值を増加させた. さらに，山柧子エキスは，投与 1 週間後から白色内 臓脂肪組織における TNF- $\alpha$ 生成を有意に低下し, 投与 2 週間後から leptin 生成も低下させた。遊離脂 肪酸生成と adiponectin 生成は投与 3 週間後に増加 させた。 以上の結果から，山栃子エキスは，高脂肪 食摂取の糖尿病態マウスの内臟脂肪組織における TNF- $\alpha$ 生成を抑制して, insulin 抵抗性を改善する ことにより，高血糖を降下させると考えられた。 ${ }^{20)}$

漢方医学において防風通聖散は体質が実証の患者 に，防已黄者湯は虚証の患者に適用されているの で，本稿では STZ-糖尿病態マウスを用いて，防風 通聖散エキスと防已黄耆湯エキスの血糖降下作用機 序を比較することにより，これらの作用機序と虚実 の適応症との関連を考察した。防風通聖散エキスの 血糖下降作用機序に山柅子エキスの作用が含まれ, その作用機序は TNF- $\alpha$ の作用の抑制であるのに対
し，防已黄者湯エキスの作用機序には TNF- $\alpha$ の作 用が関与しなかった。したがって，少なくとも STZ-糖尿病態動物を用いた本実験において，炎症 性サイトカインである TNF- $\alpha$ の発現量の増減によ り実証と虚証の分類が仮定され，TNF- $\alpha$ 発現が多 い実証には防風通聖散が，TNF- $\alpha$ 発現が少ない虚 証には防已黄者湯が奏効する可能性が推測された.

\section{6. 高脂肪食摂取肥満モデルに対する防風通聖散} の抗肥満効果

高脂肪食摂取肥満モデルマウスを用いて，防風通 聖散エキスの抗肥満作用を検討した。防風通聖散工 キスは，低脂肪食摂取正常マウスに体重減少効果を 示さなかったが，高脂肪食摂取肥満マウスの体重を 投与 5 日後から 25 日まで有意に低下させた（Fig. 12)。山柧子を除いた一味抜き方剂エキスは，体重 減少作用を示さなかったことから，防風通聖散エキ スの抗肥満作用に，山栃子が重要な役割を果たして いた。防風通聖散エキスは投与 25 日目で，白色皮 下脂肪組織や白色内臟脂肪組織重量を有意に低下さ せた（Fig. 12）. ${ }^{21)}$ 防風通聖散エキスは，投与 5 日 目では, 白色内臓脂肪組織や褐色脂肪組織の重量に 変化を与えず，白色内臓脂肪組織の uncoupling protein (UCP) 1 や UCP2, leptin, adiponectin $の$ mRNA 発現も変化しなかった。しかし，褐色脂肪 
Table 2. Effects of BTS Extract on mRNA Expression of Leptin, Adiponectin, UCP1, and UCP2 in Interscapular Brown Adipose Tissues and Epididymal White Adipose Tissues after 5-Day Administration

\begin{tabular}{|c|c|c|c|}
\hline & BTS $(-)$ & BTS $(+)$ & $p$ value \\
\hline \multicolumn{4}{|c|}{ Interscapular brown adipose tissue } \\
\hline Leptin & $0.0264 \pm 0.0080$ & $0.1182 \pm 0.0612$ & 0.0004 \\
\hline Adiponectin & $0.7679 \pm 0.2436$ & $2.5412 \pm 2.1369$ & 0.0250 \\
\hline UCP1 & $2.2519 \pm 0.9376$ & $3.3746 \pm 0.6704$ & 0.0100 \\
\hline $\mathrm{UCP} 2$ & $0.0717 \pm 0.0210$ & $0.0833 \pm 0.0430$ & 0.4781 \\
\hline \multicolumn{4}{|c|}{ Epididymal white adipose tissue } \\
\hline Leptin & $0.0512 \pm 0.0243$ & $0.0390 \pm 0.0203$ & 0.3756 \\
\hline Adiponectin & $0.6115 \pm 0.5319$ & $0.9395 \pm 0.4682$ & 0.1839 \\
\hline UCP1 & $0.0015 \pm 0.0008$ & $0.0020 \pm 0.0014$ & 0.5207 \\
\hline $\mathrm{UCP} 2$ & $0.1560 \pm 0.0252$ & $0.1777 \pm 0.0930$ & 0.5347 \\
\hline
\end{tabular}

Quantification of mRNA expression by real-time PCR was calculated relative to $\beta$-actin mRNA. Values are expressed as mean \pm S.D. $(n=4-9)$. $p$ values were calculated by Student's $t$-test. $p<0.05$, BTS group versus the control group without BTS. Reproduced, with permission, from Kobayashi et al., 2017.21)
組織における UCP1 mRNA の発現は, 白色脂肪組 織と比較して 1500 倍増加した。防風通聖散エキス は, この UCP1 mRNA の発現をさらに 1.5 倍増加 させた（Table 2)。さらに，防風通聖散エキスは leptin や adiponectin の mRNA 発現もそれぞれ 4.5 倍，3.3 倍増加させたが，UCP2 mRNA の発現は全 く変化しなかった（Table 2)。防風通聖散エキス は，投与 14 日や 25 日目において，白色内臓脂肪細 胞の大きさを有意に減少させ (Fig. 13), 投与 25 日目で血糖值と血中 insulin 值を低下させ，insulin 抵抗性も改善した（Fig. 14）。防風通聖散エキス は，さらに血中 leptin 值や triglyceride 值も低下さ せたが，血中 adiponectin 值や cholesterol 值に影響 しなかった. ${ }^{21)}$ 以上から，防風通聖散エキスは，投 与初期に褐色脂肪組織の UCP1 mRNA 発現を促進 して，熱発生によるエネルギー消費を増加して, ${ }^{22)}$
A

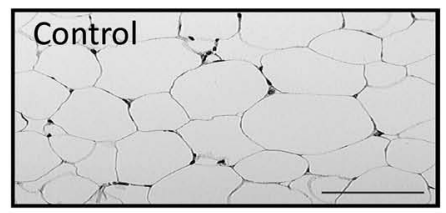

B

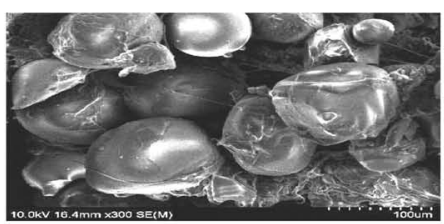

14 Days
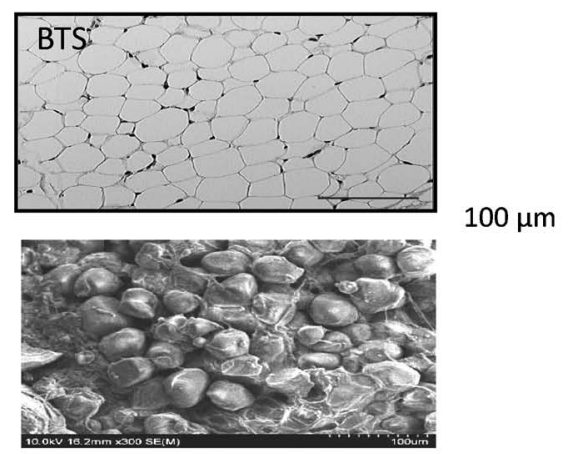

C

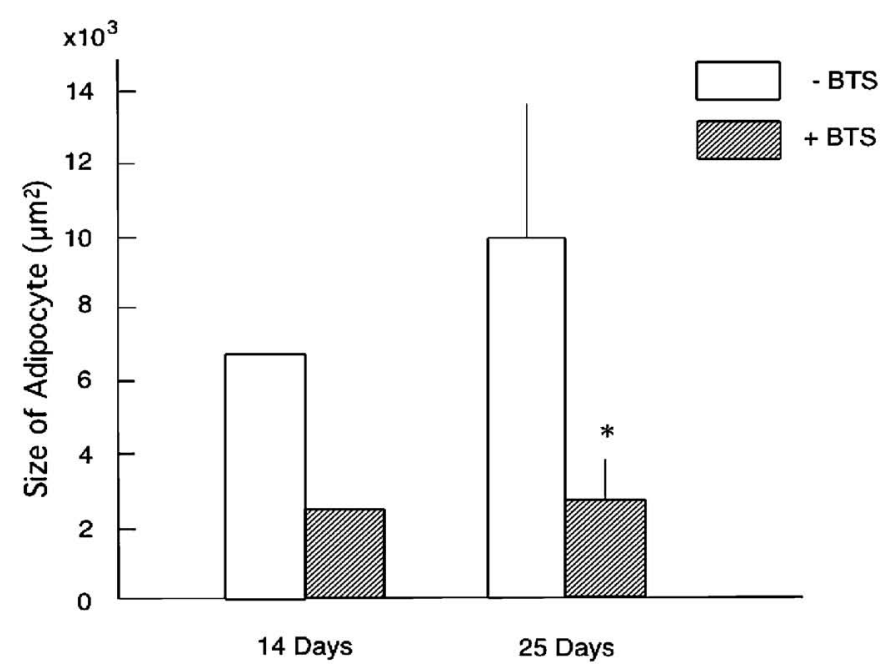

Fig. 13. Effects of BTS Extract $(2.0 \mathrm{~g} / \mathrm{kg})$ on Visceral Epididymal Adipocyte Size Under Optical Microscopy (A) and Scanning Electron Microscopy at $\times 300$ Magnification (B) After 14-Day Administration and Epididymal Adipocyte Size under Optical Microscopy after 14- and 25-Day Administration (C)

Values are expressed as mean \pm S.D. ( $n=1$ and 3, respectively). Differences between group means were evaluated by Student's $t$-test. ${ }^{*} p<0.05$ versus the control group without BTS extract. Reproduced, with permission, from Kobayashi et al., 2017.21) 

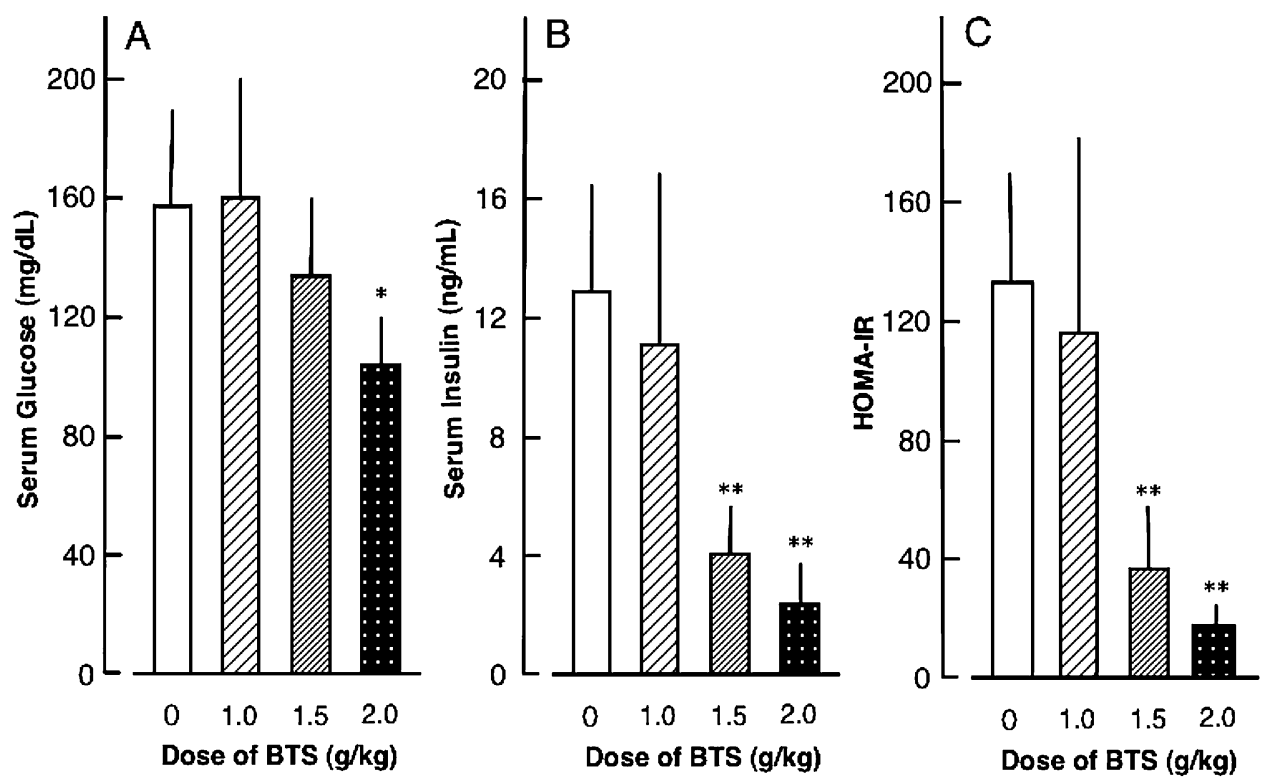

Fig. 14. Effects of BTS Extract on Serum Glucose (A), Serum Insulin (B), and HOMA-IR Values (C) in Obese Mice

HOMA-IR values were calculated as [serum glucose $(\mathrm{mg} / \mathrm{dL}) \times$ serum insulin $(\mu \mathrm{U} / \mathrm{mL})] / 405$. BTS extract $(0,1.0,1.5$, and $2.0 \mathrm{~g} / \mathrm{kg})$ was administered orally to obese mice ( 9 weeks of age) fed the HFD for $25 \mathrm{~d}$. Values are expressed as mean \pm S.D. $(n=6$ mice). Differences between group means were evaluated by Tukey's or Scheffe's test. ${ }^{*} p<0.05,{ }^{* *} p<0.01$ versus control water group without BTS extract. Reproduced, with permission from Kobayashi et al., 2017.21)

白色内臓脂肪細胞の大きさや重量を減少させると考 えられた。さらに，防風通聖散エキスは，褐色脂肪 組織の leptinの mRNA 発現も有意に促進したこと から (Table 2), leptin は，摂食抑制作用と insulin 分泌抑制作用を介して, ${ }^{23)}$ insulin 抵抗性を改善し, さらに, UCP1の生成を増強すると考えられた. ${ }^{21)}$

防風通聖散エキスは， $0.80 \%(\mathrm{w} / \mathrm{w})$ geniposide 及び 2.77\% $(\mathrm{w} / \mathrm{w})$ baicalin, $0.1 \%(\mathrm{w} / \mathrm{w})$ sennoside A, $\quad 0.14 \%(\mathrm{w} / \mathrm{w})$ total alkaloids, $0.71 \%(\mathrm{w} / \mathrm{w})$ glycyrrhizic acid, $0.26 \%(\mathrm{w} / \mathrm{w})$ paeoniflorin を含有 している. Geniposide は glucagon-like peptide-1 (GLP-1）受容体の刺激薬であるので, ${ }^{24)}$ GLP-1 と 同様に, 視床下部の adenosine monophosphate-activated protein kinase（AMPK）活性化を介して褐色 脂肪組織の発熱反応を刺激すると報告されてい る. ${ }^{25)}$ Geniposide は，さらに血中 triglyceride の分 解26)や中枢神経からの noradrenaline 遊離の刺激を 介して褐色脂肪組織での UCP1 発現を促進する. ${ }^{27)}$ 構成生薬の麻黄の成分 ephedrine は交感神経終末に 作用して noradrenaline の遊離を促進し, 褐色脂肪 細胞の発熱反応や白色脂肪細胞での脂肪分解を促進 する。また, 甘草や蓮趐, 荊芥は cyclic AMPphosphodiesterase を阻害して cyclic AMP 系反応を 刺激することにより, 褐色脂肪組織の UCP1 を発 現すると報告されている. ${ }^{28,29)}$ 今後, 防風通聖散の
一味抜き方剂や単味生薬成分の作用を詳細に検討す ることにより，防風通聖散エキスの抗肥満作用の本 体を明らかにする予定である。なお，Table 3 に英 文の Glossaries を記載して, 英文の理解に工夫を加 えた.

\section{謝辞この研究成果は, 主として北陸大学薬学} 部薬理学研究室及び臨床薬理学研究室で行ったもの であり，共同研究者である北陸大学薬学部野村政明 教授と高橋達雄准教授に厚くお礼を申し上げる，更 なる共同研究者として, 富山医科薬科大学薬学部木 村正康名誉教授，木村郁子教授，富山大学薬学部恒 枝宏史准教授, 東海大学農学部永井竜児教授, Tulane University School of Medicine Prof. Nobuyoshi Hagino, 昭和大学薬学部鳥居塚和生教授, 熊本大 学医学部堀内正公教授, 北陸大学薬学部劉 園英教 授，金沢医科大学医学部篠原治道教授，小林製薬株 式会社荒井哲也氏に心より感謝する。 また, 本研究 に協力をして頂いた薬理学・臨床薬理学研究室所属 の大学院博士課程及び修士課程, 学部の学生に感謝 する. 本研究の一部は, 文部科学省科学研究費補助 金基盤研究 $\mathrm{C}$, 学術フロンティア構想, 独立行政法 人科学技術振興機構シーズ発掘試験，北陸大学特別 研究助成などによる研究成果である. 
Table 3. Glossaries

\begin{tabular}{|c|c|c|c|}
\hline A & & glycyrrhiza & Glycyrrhiza \\
\hline \multirow[t]{2}{*}{ AMPK } & \multirow{2}{*}{$\begin{array}{l}\text { adenosine monophosphate-activated protein } \\
\text { kinase }\end{array}$} & gypsum & Gypsum \\
\hline & & \multicolumn{2}{|l|}{$\mathrm{H}$} \\
\hline angelica & Japanese Angelica Root & HFD & high-fat diet \\
\hline APDC & ammonium pyrrolidine dithiocarbamate & \multirow{2}{*}{ HOMA-IR } & \multirow{2}{*}{$\begin{array}{l}\text { homeostasis model assessment-insulin } \\
\text { resistance }\end{array}$} \\
\hline astragalus & Astragalus Root & & \\
\hline atractylodes & Atractylodes Lancea Rhizome & HSA & human serum albumin \\
\hline \multicolumn{2}{|l|}{ B } & \multicolumn{2}{|l|}{$\mathrm{J}$} \\
\hline BG & blood glucose & jujube & Jujube \\
\hline \multirow[t]{2}{*}{ BOT } & \multirow{2}{*}{$\begin{array}{l}\text { boiogito consisted of sinomenium (or stepha- } \\
\text { nia), astragalus, atractylodes, ginger, jujube } \\
\text { and glycyrrhiza }\end{array}$} & $\mathrm{K}$ & \\
\hline & & \multirow[t]{2}{*}{ KS-1-4 } & \multirow{2}{*}{$\begin{array}{l}\text { 6,7-dimethoxy-1-[ [4- [4-(6,7-dimethoxy-2- } \\
\text { methyl-1,2,3,4-tetrahydroisoquinolinyl) } \\
\text { methyl] phenoxy] benzyl] -2-methyl-1,2,3,4- } \\
\text { tetrahydroisoquinoline }\end{array}$} \\
\hline $\begin{array}{l}\text { BOT- } \\
\text { Astragalus }\end{array}$ & $\begin{array}{l}\text { prescription consisted of stephania, atrac- } \\
\text { tylodes, ginger, jujube and glycyrrhiza }\end{array}$ & & \\
\hline $\begin{array}{l}\text { BOT- } \\
\text { Atractylodes }\end{array}$ & $\begin{array}{l}\text { prescription consisted of stephania, astragalus, } \\
\text { ginger, jujube and glycyrrhiza }\end{array}$ & \multirow[t]{2}{*}{ KS-1-1 } & \multirow{2}{*}{$\begin{array}{l}\text { 6,7-dimethoxy-1-[ }[4-[5-(6,7 \text {-dimethoxy-2- } \\
\text { methyl-1,2,3,4-tetrahydroisoquinolinyl) } \\
\text { methyl-2-methoxy] phenoxy] benzyl }] \text {-2-methyl- } \\
\text { 1,2,3,4-tetrahydroisoquinoline }\end{array}$} \\
\hline BOT-Ginger & $\begin{array}{l}\text { prescription consisted of stephania, astragalus, } \\
\text { atractylodes, jujube and glycyrrhiza }\end{array}$ & & \\
\hline \multirow{2}{*}{$\begin{array}{l}\text { BOT- } \\
\text { Glycyrrhiza }\end{array}$} & \multirow{2}{*}{$\begin{array}{l}\text { prescription consisted of stephania, astragalus, } \\
\text { atractylodes, ginger and jujube }\end{array}$} & M & \\
\hline & & mentha & Mentha Herb \\
\hline \multirow[t]{2}{*}{ BOT-Jujube } & \multirow{2}{*}{$\begin{array}{l}\text { prescription consisted of stephania, astragalus, } \\
\text { atractylodes, ginger and glycyrrhiza }\end{array}$} & mirabilite & Sodium Sulfate Hydrate \\
\hline & & $\mathrm{N}$ & \\
\hline $\begin{array}{l}\text { BOT } \\
\text { (Sinomenium) }\end{array}$ & $\begin{array}{l}\text { boiogito consisted of sinomenium, astragalus, } \\
\text { atractylodes, ginger, jujube and glycyrrhiza }\end{array}$ & $\mathrm{NF}-\kappa \mathrm{B}$ & nuclear factor $\kappa \mathrm{B}$ \\
\hline \multirow{2}{*}{$\begin{array}{l}\text { BOT } \\
\text { (Stephania) }\end{array}$} & \multirow{2}{*}{$\begin{array}{l}\text { boiogito consisted of stephania, astragalus, } \\
\text { atractylodes, ginger, jujube and glycyrrhiza }\end{array}$} & $\mathrm{P}$ & \\
\hline & & PCR & polymerase chain reaction \\
\hline $\begin{array}{l}\text { BOT- } \\
\text { Stephania }\end{array}$ & $\begin{array}{l}\text { prescription consisted of astragalus, atrac- } \\
\text { tylodes, ginger, jujube, and glycyrrhiza }\end{array}$ & PDGF & platelet derived growth factor \\
\hline BTS & bofutsushosan consisted of gardenia, ephedra, & peony & Peony Root \\
\hline & glycyrrhiza, rhubarb, forsythia, mirabilite, gin- & platycodon & Platycodon Root \\
\hline & cnidium, angelica, peony, Atractylodes Rhi- & $\mathrm{R}$ & \\
\hline & zome, mentha, scutellaria, talcum and gypsum & rhubarb & Rhubarb \\
\hline $\mathrm{C}$ & & $\mathrm{S}$ & \\
\hline CML & 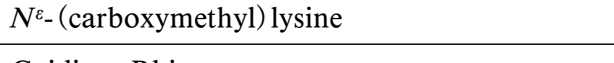 & saposhnikovia & Saposhnikovia Root and Rhizome \\
\hline cnidium & Cnidium Rhizome & schizonepeta & Schizonepeta Spike \\
\hline $\mathrm{D}$ & & scutellaria & Scutellaria Root \\
\hline DG & deoxyglucose & sinomenium & Sinomenium Stem and Rhizome \\
\hline DMEM & Dulbecco's modified Eagle's medium & stephania & Stephania tetrandra S. Moore root \\
\hline E & & STZ & streptozotocin \\
\hline ELISA & enzyme-linked immunosorbent assay & $\mathrm{T}$ & \\
\hline ephedra & Ephedra Herb & talcum & Aluminium Silicate Hydrate with Silicon \\
\hline $\mathrm{F}$ & & & Dioxide \\
\hline FBS & fetal bovine serum & TNF & tumor necrosis factor \\
\hline forsythia & Forsythia Fruit & $\mathrm{U}$ & \\
\hline G & & UCP1 & uncoupling protein 1 \\
\hline gardenia & Gardenia Fruit & $\mathrm{V}$ & \\
\hline ginger & Ginger & VEGF & vascular endothelial growth factor \\
\hline
\end{tabular}

The English names of crude drugs were quoted from The Japanese Pharmacopoeia, Seventeenth Edition. 
利益相反 本稿の著者である古林伸二郎は，小 林製薬株式会社から奨学（奨励）寄付金と防風通聖 散エキス試料を供与された.

\section{REFERENCES}

1) Kobayashi S., J. Trad. Med., 13, 18-26 (1996).

2) Liu Y. Y., Kobayashi S., Tsutsumi T., Kontani H., J. Trad. Med., 17, 253-260 (2000).

3) Tsutsumi T., Kobayashi S., Liu Y. Y., Kontani H., Biol. Pharm. Bull., 26, 313-317 (2003).

4) Ma W., Nomura M., Takahashi-Nishioka T., Kobayashi S., Biol. Pharm. Bull., 30, 20792083 (2007).

5) Ishibashi T., Murata T., Hangai M., Nagai R., Horiuchi S., Lopez P. F., Hinton D. R., Ryan S. J., Arch. Ophthalmol., 116, 16291632 (1998).

6) Ikeda K., Higashi T., Sano H., Jinnouchi Y., Yoshida M., Araki T., Ueda S., Horiuchi S., Biochemistry, 35, 8075-8083 (1996).

7) Kobayashi S., Shinohara H., Tsuneki H., Nagai R., Horiuchi S., Biol. Pharm. Bull., 27, 1382-1387 (2004).

8) Kobayashi S., Suzuki M., Tsuneki H., Nagai R., Horiuchi S., Hagino N., Biol. Pharm. Bull., 27, 1565-1571 (2004).

9) Hagino N., Kobayashi S., Tsutsumi T., Horiuchi S., Nagai R., Setalo G., Dettrich E., Brain Res. Bull., 62, 537-547 (2004).

10) Hagino N., Kobayashi S., "Mind in Aging," Scientific Research Publishing, Irvine, 2017.

11) Kobayashi S., Nomura M., Nishioka T., Kikuchi M., Ishihara A., Nagai R., Hagino N., Biol. Pharm. Bull., 30, 133-138 (2007).

12) Liang X.-C., Hagino N., Guo S.-S., Tsutsumi T., Kobayashi S., Phytomedicine, 9, 377-384 (2002).

13) Kobayashi S., Kimura I., Fukuta M., Kontani H., Inaba K., Niwa M., Mita S., Kimura M., Biol. Pharm. Bull., 22, 360-365 (1999).

14) Schreck R., Meier B., Männel D. N., Dröge W., Baeuerle P. A., J. Exp. Med., 175, 11811194 (1992).

15） Kikuchi M., Kamimura S., Nomura M., Takahashi T., Hagino N., Kobayashi S., Chin. Med., 1, 75-83 (2010).
16) Yu Q., Yasuda M., Takahashi T., Nomura M., Hagino N., Kobayashi S., Chin. Med., 2, 130-137 (2011).

17) Yu Q., Takahashi T., Nomura M., Yasuda M., Obatake I. K., Kobayashi S., Chin. Med., 4, 24-31 (2013).

18) Yu Q., Takahashi T., Nomura M., Kobayashi S., Chin. Med., 4, 157-165 (2013).

19) Kusakabe T., Tanioka H., Ebihara K., Hirata M., Miyamoto L., Miyanaga F., Hige H., Aotani D., Fujisawa T., Masuzaki H., Hosoda K., Nakao K., Diabetologia, 52, 675-683 (2009).

20) Yu Q., Takahashi T., Nomura M., Matsuo Y. I., Kobayashi S., Asian J. Trad. Med., 12, 1930 (2017).

21) Kobayashi S., Kawasaki Y., Takahashi T., Maeno H., Nomura M., Chin. Med., 12, 8 (2017).

22) Cannon B., Nedergaard J., Physiol. Rev., 84, 277-359 (2004) .

23) Kieffer T. J., Heller R. S., Leech C. A, Holz G. G., Habener J. F., Diabetes, 46, 1087-1093 (1997).

24） Liu J., Yin F., Zheng X., Jing J., Hu Y., Neurochem. Int., 51, 361-369 (2007).

25) Beiroa D., Imbernon M., Gallego R., Senra A., Herranz D., Villarroya F., Serrano M., Fernø J., Salvador J., Escalada J., Dieguez C., Lopez M., Frühbeck G., Nogueiras R., Diabetes, 63, 3346-3358 (2014) .

26) Sasaki T., Nakata R., Inoue H., Shimizu M., Inoue J., Sato R., Am. J. Physiol. Endocrinol. Metab., 306, E1085-E1092 (2014).

27) Saltiel A. R., Proc. Natl. Acad. Sci. USA, 97, 535-537 (2000).

28) Yoshida T., Sakane N., Wakabayashi Y., Umekawa T., Kondo M., Int. J. Obes. Relat. Metab. Disord., 19, 717-722 (1995).

29) Azushima K., Tamura K., Haku S., Wakui H., Kanaoka T., Ohsawa M., Uneda K., Kobayashi R., Ohki K., Dejima T., Maeda A., Hashimoto T., Oshikawa J., Kobayashi Y., Nomura K., Azushima C., Takeshita Y., Fujino R., Uchida K., Shibuya K., Ando D., Tokita Y., Fujikawa T., Toya Y., Umemura S., Atherosclerosis, 240, 297-304 (2015) . 